\title{
Gradients in Seasonality and Seawater Oxygen Isotopic Composition along the Early Permian Gondwanan Coast, SE Australia
}

1

2

3

4

\section{J. Andrew Beard ${ }^{1}$}

Department of Earth Sciences, Syracuse University, Syracuse NY 13244-1070, USA james.beard@uconn.edu

\section{Linda C. Ivany ${ }^{2}$}

Department of Earth Sciences, Syracuse University, Syracuse NY 13244-1070, USA Icivany@syr.edu; 1-315-443-3626

\section{Bruce Runnegar}

Department of Earth, Planetary and Space Sciences, University of California, Los Angeles, CA 90095-1567, USA

runnegar@ucla.edu

${ }^{1}$ Present address: Center for Integrative Geosciences, University of Connecticut, Storrs, CT 06269-2045, USA

${ }^{2}$ Corresponding author

Final Revision for Earth and Planetary Science Letters (Ms. Ref. No.: EPSL-D-14-01335)

\section{Abstract}

Oxygen isotope compositions of marine carbonates are commonly employed for understanding ancient temperatures, but this approach is complicated in the very distant past due to uncertainties about the effects of diagenesis and the isotopic composition of seawater, both locally and globally. Microsampled accretionary calcite from two species of the fossil bivalve Eurydesma Sowerby and Morris 1845 collected from sediments of Cisuralian age in high latitude marine sediments along the SE coast of Australia record cyclic seasonal fluctuations in shell $\delta^{18} \mathrm{O}$ values during growth, demonstrating the primary nature of the isotope signal and thus allowing investigation of early Permian seawater isotopic composition and water 
32 temperature in the high southern latitudes. The mean and seasonal range of $\delta^{18} \mathrm{O}_{\text {carb }}$ decrease

33 poleward across about $10^{\circ}$ of paleolatitude $\left(\sim 67^{\circ} \mathrm{S}-77^{\circ} \mathrm{S}\right)$. The presence of co-occurring

34 dropstones and stratigraphically associated glendonites constrain winter temperatures across

35 the region to near-freezing, thus permitting calculation of realistic estimates of water composition and summer temperatures. Summer $\delta^{18} \mathrm{O}_{\text {carb }}$ values indicate water temperatures

37 between $5^{\circ} \mathrm{C}$ and $12^{\circ} \mathrm{C}$, with warmer values at lower latitudes. The decrease in both mean sea

38 surface temperature and seasonal amplitude with increasing latitude on the Gondwanan coast

39 is much like that observed along high-latitude coastlines today. Calculated $\delta^{18} \mathrm{O}_{\text {water }}$ decreases toward the pole, likely associated with an increasing contribution of isotopically light fresh

41 water derived from summer snow-melt. The gradient in $\delta^{18} \mathrm{O}_{\text {water }}$ is similar to that documented

42 over a similar span of latitude on the modern SE Greenland coast. We infer the presence of a

43 north-flowing coastal current of cold, $\mathrm{O}^{18}$-depleted water that entrains progressively greater

44 amounts of more typical seawater as it moves away from the pole. $\delta^{18} \mathrm{O}$ values in SE Australia,

45 however, are about 3\%o lower than those off Greenland, suggesting comparatively lower

46 salinity water or more $\mathrm{O}^{18}$-depleted glacial ice/runoff in the Permian Gondwanan high latitudes,

47 perhaps augmented by more depleted (negative) global average seawater. Conditions in

48 southeastern Australia during the largest of the Permian deglaciations were warmer than

49 present-day Antarctica at similar latitudes, but may approximate those of early-mid Miocene

50 Antarctica, with frozen winters but summers closer to $10^{\circ} \mathrm{C}$.

51

\section{Keywords}

53 oxygen isotope, Permian, Gondwana, seasonality, seawater, bivalve, Eurydesma 


\section{Introduction}

Global climate began the transition from an icehouse to a greenhouse state during the

57 early Permian (Cisuralian, 299-272 Ma). Because continental ice sheets had contracted significantly in size, the early Permian offers similarities to the waning of modern ice sheets, and hence there is great interest in constraining paleoclimate over that transition (e.g., 2013).

60 Detailed stratigraphic, geochemical, and paleobotanical studies have done much to clarify the 61 conditions associated with deglaciation, but quantitative estimates of paleotemperature

62 through this interval have been fraught with the uncertainties that accompany studies of the

63 very distant past (e.g., Frank et al., 2008a; Korte et al., 2005, 2008; Rees et al., 2002). While

64 stable oxygen isotope compositions have proved invaluable for reconstructing Cenozoic

65 climate, applying this proxy in deep time is difficult due to the potential for diagenetic

66 alteration of the original isotopic compositions. This concern becomes progressively worse in

67 older samples due to the greater likelihood of exchange with diagenetic fluids and thermal resetting (e.g., see Grossman, 2012, and references therein). A growing number of authors have nevertheless used stable oxygen isotope values, usually of brachiopod and bivalve shell

70 fragments or sections, in the later part of the Paleozoic to interpret climate from marine

71 carbonates (e.g., Angiolini et al., 2009; Brand, 2004; 2012; 2009; Frank et al., 2008a; 2012;

72 Grossman, 2010; Grossman and Mii, 1996; Grossman et al., 1993; 2008; Korte et al., 2005;

73 2008; Lowenstam, 1961; Mii and Grossman, 1994; Mii et al., 1997, 1999; 2001; Popp et al.,

74 1986; Rao and Green, 1982; Veizer et al., 1997; 1986). These studies have vastly improved our

75 understanding of conditions during this transition, yet they still face the pervasive challenge of 
demonstrating the primary nature of isotopic compositions, and most lack the spatial resolution within individual specimens necessary to address questions of seasonality (but see Ivany and Runnegar, 2010; Mii et al., 2012; Seuss et al., 2012), a component of climate that is gaining attention in studies of deep earth history.

Here, we report stable isotope data from early Permian bivalves sampled sequentially at high spatial resolution within shells. This approach has been widely used in younger specimens

82 to resolve seasonal environmental variation recorded by organisms that produce a carbonate skeleton by accretion (see reviews by Gröcke and Gillikin, 2008; Ivany, 2012; Jones and Quitmyer, 1996; Schöne and Surge, 2012). Isotope data come from shells of the bivalves Eurydesma cordatum Morris 1845 and E. hobartense Johnston 1887 from SE Australia that span roughly $1100 \mathrm{~km}$ of the modern outcrop belt. Eurydesma is a cold-water, high-latitude, calcitic

87 bivalve characteristic of the Permian of Gondwana (Runnegar, 1970; 1979). Specimen locations range from the northern Sydney Basin (NSB) at $\sim 67^{\circ} \mathrm{S}$ paleolatitude through the southern Sydney Basin (SSB) at paleolatitude $\sim 70^{\circ} \mathrm{S}$ to the Tasmanian Basin (TAS) at $\sim 77^{\circ} \mathrm{S}$ paleolatitude (Klootwijk, 2009; Li and Powell, 2001; Schmidt and Clark, 2000; Scotese, 1997; Stampfli and Borel, 2002), and shells are closely associated stratigraphically with sedimentologic and

92 mineralogic indicators of freezing conditions. Seasonally resolved records of $\delta^{18} \mathrm{O}_{\text {carb }}$ not only 93 afford an additional method by which to evaluate the influence of diagenesis on ancient shell 94 carbonate (through preservation of a repeated seasonal cycle throughout ontogeny), but can 95 also provide estimates of paleoseasonality of water temperatures on the early Permian 96 97 Gondwanan coast. In addition, by sampling across a range of paleolatitudes and from sites with independent evidence for cold temperatures, it is possible to place constraints on regional 
differences in water composition that might relate to latitudinal gradients associated with the Permian hydrologic cycle. Such information can provide greater clarity on the nature of climate conditions during Permian deglaciation.

\section{Geologic setting and depositional environment}

During the early Permian, Australia was connected to Antarctica and located close to the South Pole in the southern-most portion of Pangaea (Figure 1). Sediments considered here were deposited on the continental margin atop older Paleozoic basement or concordantly underlying Carboniferous strata. Specimens of Eurydesma are from shallow-water, marine, sedimentary rocks of Cisuralian (Sakmarian-Artinskian) and Guadalupian (Roadian) age that include the volcanogenic sandstones and conglomerates of the "Millfield Farm member" (informal name) of the Dalwood Group, the Allandale Formation, and the Cranky Corner Sandstone, NSB (McClung, 1980a, b; Runnegar, 1979); the pebbly sandstones of the Wasp Head Formation, SSB (Runnegar, 1970, 1980a, b; Rygel et al., 2008); and the pebbly Bundella Mudstone and dropstone-rich, fossiliferous Darlington Limestone, TAS (Clarke, 1989; Fielding et al., 2006; 2010; Isbell et al., 2012) (Figure 2; see Supplementary Information for details on stratigraphy, correlation, age control, and proximity to glacial intervals). In addition, the younger early Guadalupian (Roadian) and deeper-water Wandrawandian Siltstone (Runnegar, 1980b; Thomas et al., 2007) was also sampled. Commonly associated fossils include the epifaunal bivalve Deltopecten, the spiriferoid brachiopods Trigonotreta and Ingelarella, and fenestellid and trepostome bryozoans; other semi-infaunal and infaunal bivalves, crinoids, gastropods, rugose and tabulate corals, and productoid brachiopods are also variably present 
(Clapham and James, 2008; Clarke, 1969, 1992; McClung, 1980a; Reid, 2010; Runnegar, 1969b;

Runnegar, 1979; Runnegar, 1980a). These assemblages of organisms are characteristic of open marine shelf conditions and therefore indicate fairly normal marine salinities (Clapham and James, 2008). Brachiopods in particular are today nearly all restricted to salinities above $30 \mathrm{ppt}$ (Brand et al., 2003).

5

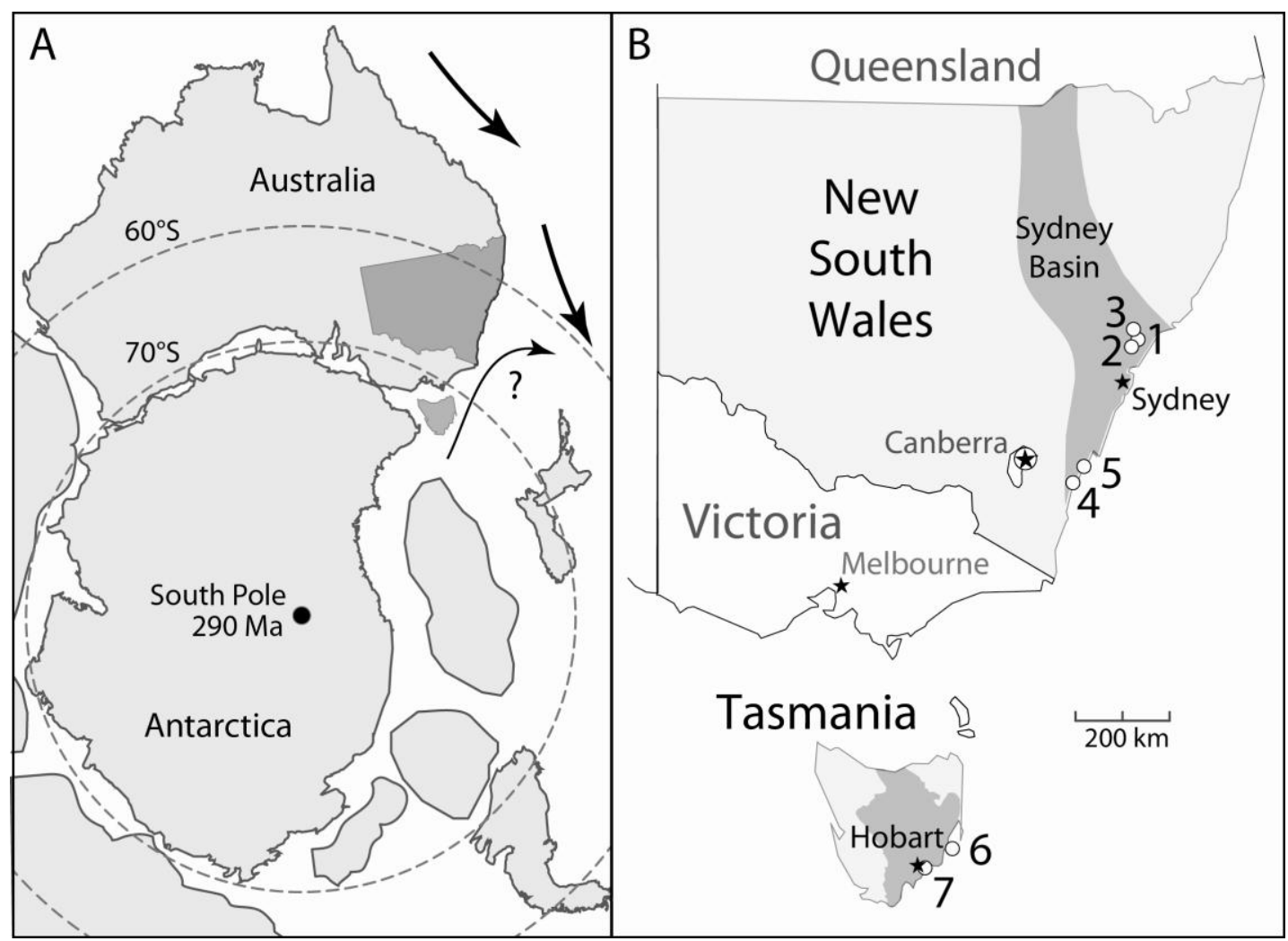

Figure 1. A) Paleogeographic reconstruction for $290 \mathrm{Ma}$, based on Scotese (2001), Li and Powell (2001), and Fielding et al. (2010); New South Wales and Tasmania in dark shading. Heavy arrows mark inferred ocean surface currents from Winguth et al. (2002) and Jones et al. (2006); thinner arrow with "?" is our inferred boundary current. B) Locations of sample sites in SE Australia on modern geography (1 - Allandale, 2 - Bimbadeen, 3 - Greenlees and DM Tangorin DDH1, 4 - Wasp Head, 5 - North Head at Ulladulla, 6 - Maria Island, 7 - Derwent River at Taroona). Bowen-Gunnedah-Sydney and Tasmanian Basin systems are indicated by dark shading. (1.5 column width) 


\begin{tabular}{|c|c|c|c|c|c|}
\hline AGE (Ma) & EPOCH & STAGE & N Sydney Basin & S Sydney Basin & Tasmania \\
\hline 272 & GUADALUPIAN & ROADIAN & $\begin{array}{l}\text { BRANXTON } \\
\text { FORMATION }\end{array}$ & $\begin{array}{l}\text { WANDRAWANDIAN } \\
\text { SILTSTONE }\end{array}$ & $\begin{array}{l}\text { DEEP BAY } \\
\text { FORMATION }\end{array}$ \\
\hline 283 & & $\begin{array}{c}K \\
U \\
N \\
G \\
U \\
R \\
\text { I } \\
A \\
N\end{array}$ & $\begin{array}{c}\text { MEASURES } \\
\text { FARLEY } \\
\text { FORMATION } \\
\text { R } \\
\text { U } \\
T \\
H \\
\text { E } \\
\text { R } \\
\text { F } \\
\text { O }\end{array}$ & $\begin{array}{c}\text { POINT } \\
\text { FORMATION } \\
\text { P } \\
\text { E } \\
\text { B } \\
\text { B } \\
\text { L } \\
\text { E } \\
\text { Y } \\
\text { B } \\
\text { E }\end{array}$ & $\begin{array}{l}\text { FAULKNER } \\
\text { AND } \\
\text { LFFEY } \\
\text { GROUPS }\end{array}$ \\
\hline 290 & & $\begin{array}{l}\text { A } \\
\text { R } \\
T \\
\text { I } \\
\text { N } \\
\text { S } \\
\text { K } \\
\text { I } \\
\text { A } \\
\text { N }\end{array}$ & $\begin{array}{c}\text { R } \\
\text { D } \\
\text { Millfield Farm Mbr } \\
\text { ALLANDALE } \\
\text { FORMATION } \\
\text { Cranky Corner Sst }\end{array}$ & $\begin{array}{c}\text { A } \\
\mathrm{C} \\
\mathrm{H} \\
\text { WASP } \\
\text { HEAD } \\
\text { FORMATION }\end{array}$ & $\begin{array}{l}\text { BUNDELLA } \\
\text { FORMATION } \\
\text { DARLINGTON } \\
\text { LIMESTONE }\end{array}$ \\
\hline 295 & & $\begin{array}{l}\text { S } \\
\text { A } \\
K \\
\text { M } \\
\text { A } \\
\text { A } \\
1 \\
\text { A } \\
\text { N } \\
\end{array}$ & $\begin{array}{l}\mathrm{L} \\
\mathrm{O} \\
\mathrm{C} \\
\mathrm{H} \\
\mathrm{I}\end{array}$ & & $\begin{array}{c}\text { QUAMBY \& } \\
\text { WOODY ISLAND } \\
\text { SILTSTONES }\end{array}$ \\
\hline 9 & & $\begin{array}{l}\text { A } \\
\text { S } \\
\text { S } \\
\text { E } \\
\text { L } \\
\end{array}$ & $\begin{array}{l}\mathrm{V} \\
\mathrm{A} \\
\mathrm{R}\end{array}$ & $\begin{array}{l}-?- \\
\text { TALLONG } \\
\text { TILLITE } \\
-?-\end{array}$ & $\begin{array}{l}\text { STOCKERS \& } \\
\text { TURO TILLITES }\end{array}$ \\
\hline
\end{tabular}

138 Figure 2. Stratigraphic relationships among lower Permian units in SE Australia. Bold-faced units are those sampled in this study Most of the samples studied are of Artinskian age according to available $\mathrm{U}-\mathrm{Pb}$ ages from eastern Australia, but have traditionally been considered older (Sakmarian). One site (UNE L901, North Head, Ulladulla, NSW) is probably early Guadalupian (Roadian) in age. See Supplementary Information for additional detail on stratigraphy, correlation, and age control. (1.5 column width)

147 (Bembrick and Holmes, 1976; Crowell and Frakes, 1971; Eyles et al., 1997; Fielding et al., 2006;

148 Fielding et al., 2010; Frank et al., 2008b; Selleck et al., 2007). The Darlington Limestone in 149 particular contains numerous layers of dropstones, some of which are very large (Fielding et al., 150 2008b; 2010; Isbell et al., 2012; Reid, 2010; Runnegar, 1979). Glendonites are calcite 
151 pseudomorphs after the mineral ikaite $\left(\mathrm{CaCO}_{3} \cdot 6 \mathrm{H}_{2} \mathrm{O}\right)$, an authigenic hydrated calcium carbonate

152 that forms in sediments at temperatures below $\sim 4^{\circ} \mathrm{C}$ (Bischoff et al., 1993; Marland, 1975;

153 Selleck et al., 2007; Suess et al., 1982) and hence constrains depositional temperatures to near

154 freezing, at least during winters. Glendonites are unlikely to directly co-occur with Eurydesma

155 because they mostly form in organic-rich muds (Frank et al., 2008b), whereas Eurydesma

156 preferred clean, high-energy sandy to gravelly environments (Runnegar, 1979). Nevertheless,

157 glendonites have been found in close stratigraphic proximity to Eurydesma in the Cygnet-

158 Woody Island siltstones and overlying Bundella Mudstone, Tasmania (Clarke, 1992; Fielding et

159 al., 2010), and in the Allandale Formation, Pebbley Beach Formation, Wandrawandian Siltstone,

160 and Branxton Formation of the Sydney Basin (Woolnough, 1910)(see additional detail in

161 Supplementary Information), providing clear indications of cold conditions.

162

\section{Eurydesma cordatum and E. hobartense}

Eurydesma was an immobile epifaunal bivalve with heavily calcified umbones that acted

as an anchor to help maintain its preferred hinge-down orientation in high energy

166

environments with low sedimentation rates (Runnegar, 1979). While its specific taxonomic

167 affinity is uncertain, it belongs to the Subclass Pteriomorphia (Runnegar, 1979), the group that

168 includes the oysters, marine mussels, pectens, and arcs (Bieler et al., 2014). The thick umbones

169 of Eurydesma are comprised of stable, low-Mg calcite, and offer an ideal platform for

170 micromilling, having well-defined and expanded growth lines (Figure 3). Bivalves, including

171 pteriomorphs, are known to precipitate calcite in isotopic equilibrium with water (e.g.,

172 Chauvaud et al., 2005; Epstein et al., 1953; Kirby et al., 1998; Klein et al., 1996; Mook and Vogel, 
173 1968; Surge et al., 2001), making paleotemperature reconstruction possible. Earlier isotopic

174 work on Eurydesma has demonstrated regular cyclic variations in shell $\delta^{18} \mathrm{O}$ and that alternating

175 light and dark growth bands are seasonal, with the lighter-colored regions exhibiting periods of

176 faster growth during the warmer months and darker bands representing periods of slower

177 growth and/or growth cessation during winter (Figure 3; Ivany and Runnegar, 2010). Here we

178 sample two closely related and co-occurring species of Eurydesma, E. cordatum and E.

179 hobartense, which differ only in the degree of convexity and thickness of the umbonal regions

180 of the shell.

181

182

183

184

185

186

187

188

189

190

191

192

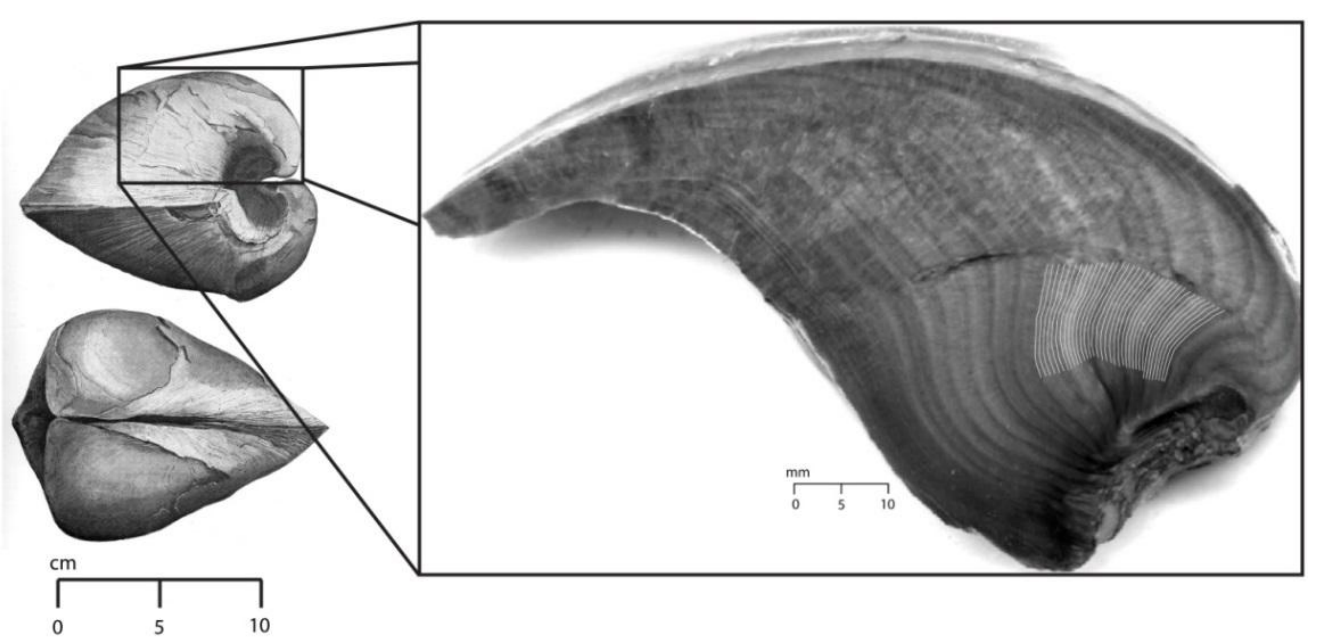

Figure 3. Eurydesma cordatum Morris 1845 (left) after Etheridge and Dun (1910), with inset showing cross section through the umbo of specimen MIsA from Maria Island, Tasmania. Digitized image of sampling lines is superimposed on growth banding. Note the prominent annual growth bands. (1.5 column width)

\section{Ages of samples studied and relation to Gondwanan glaciation}

The "Eurydesma beds" of the Allandale Formation (McClung, 1980a; Osborne, 1949;

Percival et al., 2012; Runnegar, 1979; Walkom, 1912) and the Cranky Corner Sandstone 
193 (Osborne, 1949; Slee, 1968; Stevenson, 2003) of the NSB; the Darlington Limestone at Fossil

194 Cliff at the north end of Maria Island, Tasmania (Clarke and Baillie, 1984; Fielding et al., 2010;

195 Isbell et al., 2012; Runnegar, 1979); and the upper part of the Wasp Head Formation, SSB

196 (Cisterna and Shi, 2014; Gostin and Herbert, 1973; Runnegar, 1969b; Rygel et al., 2008), have

197 long been considered approximately equivalent in age (Briggs, 1998; Clarke, 1992; Dickins,

198 1996; Runnegar, 1969a) because of the co-occurrence of the following common and widely

199 distributed species that are confined to the middle and late Tamarian stage of Tasmania

200 (Clarke, 1992) and to the Ingelarella konincki zone in the Sydney Basin (McClung, 1978):

201 Deltopecten illawarensis (Morris), Eurydesma cordatum Morris, Megadesmus globosus

202 Sowerby, Pyramus laevis (Sowerby), Ingelarella konincki (Etheridge), Pseudosyrinx allandalensis

203 Armstrong, Strophalosia subcircularis Clarke, Trigonotreta stokesi Koenig. Correlation of these

204 cold temperate bivalve and brachiopod species with the international standard stages via the

205 warmer temperate faunas of Western Australia has always been problematical, but a long-

206 prevailing view is that they are Asselian-Sakmarian in age (Briggs, 1998; Dickins, 1970; Fielding

207 et al., 2008b; Isbell et al., 2012; Retallack et al., 2011; Runnegar, 1969a; Waterhouse, 2008).

208 However, four in-sequence Sensitive High-Resolution lon Microprobe (SHRIMP) U-Pb ages for

209 the Cranky Corner Sandstone $(284.1 \pm 2.2 \mathrm{Ma})$, underlying Beckers Formation $(287.1 \pm 2.4 \mathrm{Ma})$,

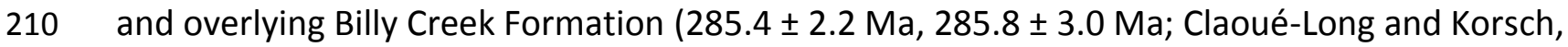

2112003 ) all fall within error in the Artinskian as currently calibrated (290.1-283.5 Ma).

212 Unfortunately, the SL13 zircon standard used for that study was subsequently shown to be

213 sufficiently inhomogeneous in $\mathrm{U} / \mathrm{Pb}$ so as to give more variable ages than other ion probe

214 standards, and ones that tend to be younger than IDTIMS ages by 1\% (Black et al., 2003; see 
215 also Tucker and McKerrow, 1995). Even so, the Cranky Corner Sandstone and correlative units 216 seem unlikely to be older than Sakmarian-Artinskian based on these SHRIMP ages, which have 217 been adjusted downwards by 1\% following Black et al. (2003; Supplemental Figure S1). (Allandale, UCLA 7385; Bimbadeen, UNE L1113A; Cranky Corner, UNE L1292; Maria Island, UQ L3048; Wasp Head, UNE L867) must be well-separated stratigraphically from the Gondwanawide glaciation that straddled the Carboniferous-Permian boundary and persisted into the

222 Asselian (Fielding et al., 2008a; Fielding et al., 2008c; Montañez and Poulsen, 2013). The 223 youngest proximal records of the P1 glacial interval in the areas studied are the 224 Truro/Stockers/Wynyard Tillites in Tasmania (Isbell et al., 2012), the breccias at the base of the 225 Wasp Head Formation in the SSB (Rygel et al., 2008), and a poorly exposed diamictitic interval 226 in the lower Lochinvar Formation in the NSB (Dickins and Sullivan, 1979). In each case, our 227 sampled horizons are separated from local glacial indicators by at least two paleontological 228 zones, possibly corresponding to most of the Sakmarian. units during and just after the waning stages of P1 glaciation and interpret overlying sediments 231 of the lower Pebbley Beach Formation and equivalents as representing another widespread 232 glacial expansion (P2) centered in New South Wales. Isbell et al. (2012), however, characterized 233 the interval in question in Tasmania as "postglacial" and suggested that evident ice rafting was 234 by sea ice rather than icebergs; similar views were expressed by Clarke and Farmer (1982) and 235 Dickins (1985). Sakmarian SHRIMP U-Pb ages from volcanics (Halls Peak Volcanics, Cawood et 236 al., 2012; Alum Rock rhyolite, Roberts et al., 1996; Brogans Rhyodacite, Roberts et al., 2006) 
237 that underlie even older Permian faunas in the Gunnedah Basin and southern New England

238 Orogen (Briggs, 1998; Degeling and Runnegar, 1979; McClung, 1978) provide additional

239 evidence for the extended interval of time (up to $8 \mathrm{Ma}$, Supplementary Figure S2) between the

240 last of the eastern Australian ice sheets and the Eurydesma shells sampled in this study

241 (Supplemental Figure S1). Whether an ice sheet is still present somewhere in eastern Australia

242 at this time is still debated, but the deposition of these units under generally cold conditions is

243 not. These sediments are well below the greenhouse climate crises in the Sydney Basin

244 recognized by Retallack (2013; Retallack et al., 2011) and dated to the early middle Roadian and

245 younger by Metcalfe et al. (2014).

246

247

\section{Methods}

248

Specimens were cut through the umbo perpendicular to growth and polished to reveal

249 growth banding. Thin sections were prepared for the examination of shell textures and thick

250 sections were prepared from the immediately adjacent slab for micromilling. Three or more

251 spot samples were collected from each thick section for evaluation of diagenetic alteration

252 using minor element ( $\mathrm{Fe}, \mathrm{Mn}$ ) concentrations; analyses were carried out using the quadrupole

253 ICP-MS at SUNY-Oswego. Thick sections were spot sampled for initial evaluation of stable

254 isotope values (Supplementary Information), and 8 shells were micromilled at a resolution of 6

255 samples per year over 5 consecutive years. Sampling was done in the central region of the

256 umbo in cross section to minimize potential exposure to diagenetic fluids, and near the faster-

257 growing, juvenile portion of the ontogeny so as to exploit the more expanded growth lines and

258 hence achieve better temporal resolution. Any evident cracks or microborings were avoided, 
but several samples from obviously secondary cements filling such structures at or near the

exterior surface of shells were collected for comparison with shell isotope values. Stable

261 isotope analyses $\left(\delta^{18} \mathrm{O}\right.$ and $\left.\delta^{13} \mathrm{C}\right)$ were performed at the University of Kansas using a Finnigan

262

263

264

265

266

267

268

269

270

271

272

273

274

275

276

277

MAT 253 isotope ratio mass spectrometer coupled to a KIEL III automated carbonate reaction device. Paleolatitudes for each site were determined as described in Supplementary

Information.

\section{Results}

Thin sections reveal shell fabrics with prismatic elongate calcite crystals oriented perpendicular to comarginal growth banding (Figure 4). Crystals exhibit undulatory extinction and microgrowth increments similar to primary shell textures seen in other pteriomorph bivalves such as Pinna bicolor (Carter and Stehli, 1980). Fe and Mn concentrations from the
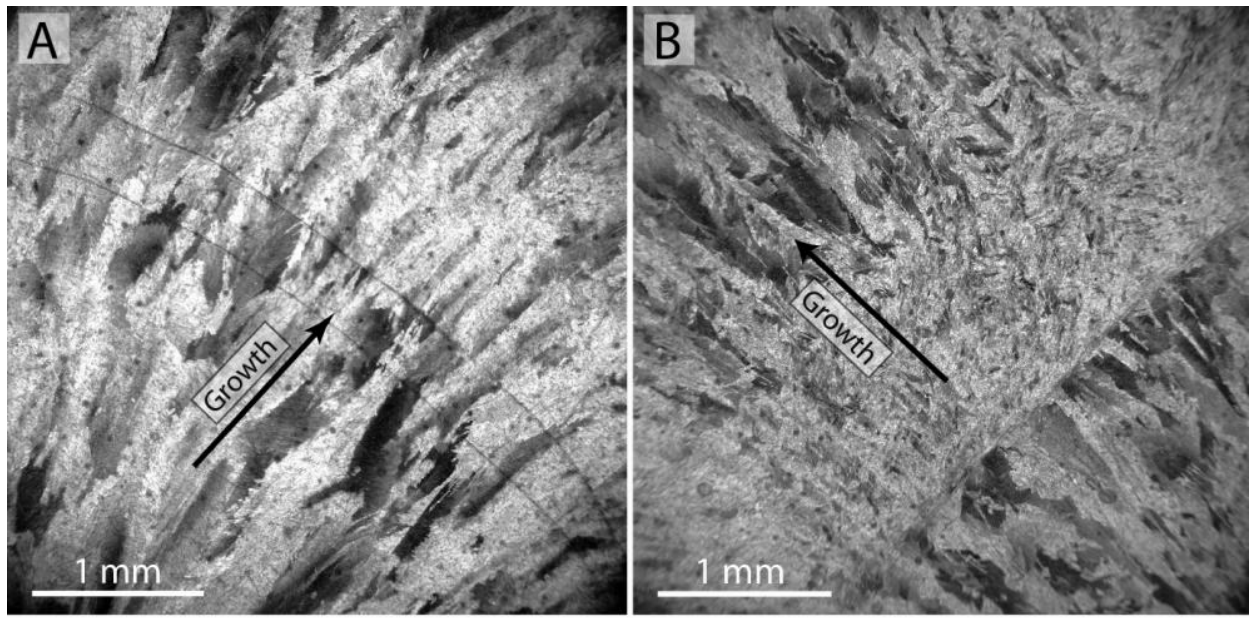

Figure 4. Photomicrographs of Eurydesma specimens from (A) Maria Island and (B) North Head, in plane-polarized light. Note elongate complex prismatic crystals oriented parallel to the direction of growth, and changes in crystal size associated with co-marginal growth increments. (1.5 column width) 
central region of Eurydesma shell umbos averaged $66 \pm 67 \mathrm{ppm}$ and $11 \pm 4 \mathrm{ppm}$, respectively, and many were at or below the detection limit for Fe at 5ppm. Samples plot within the range reported for 'well-preserved' Permian bivalves and brachiopods (Korte et al., 2008; Mii et al., 2012) and for modern brachiopods (Brand et al., 2003; Came et al., 2014)(Figure 5). Modern calcitic and mixed-mineralic bivalves have similar upper limits for Fe and slightly lower limits for Mn (Cravo et al., 2007; Morrison and Brand, 1986), though still in excess of all our shell data.

Crack-filling and shell-surface cements and a micro-boring infill, clearly secondary and collected for comparison with the umbonal calcite where stable isotope sampling was done, exhibit Mn $>300 p p m$ and/or Fe >1,000ppm.

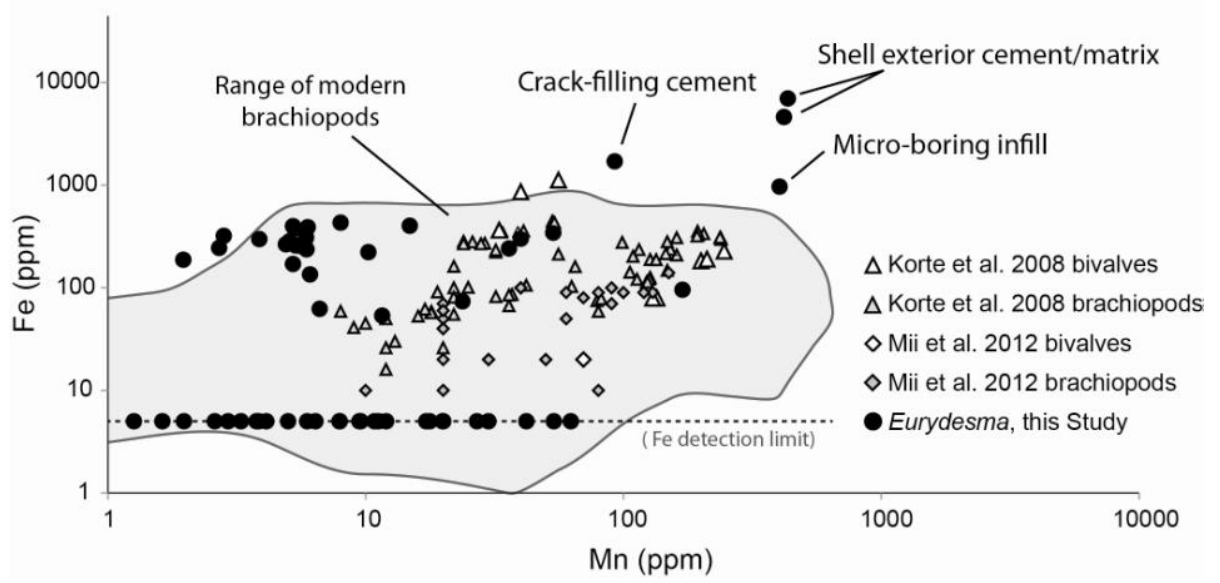

Figure 5. The concentrations of Fe and Mn from our Eurydesma samples (solid black dots) in comparison to published data from Permian bivalves and brachiopods deemed to be wellpreserved (Korte et al. 2008; Mii et al. 2012). The gray field represents the region occupied by modern brachiopods from Brand et al. (2003); modern calcitic and mixed-mineralic bivalves are comparable for Fe and slightly lower in Mn (Cravo et al., 2007; Morrison and Brand 1986). Fe and $\mathrm{Mn}$ concentrations of 1,000 ppm and $300 \mathrm{ppm}$, respectively, are the limits beyond which alteration is suspected. (1.5 column width)

Plots of carbonate $\delta^{18} \mathrm{O}$ values versus distance along the growth axis define regular cyclic variation in all but one of the specimens, as expected for shell accretion that records 

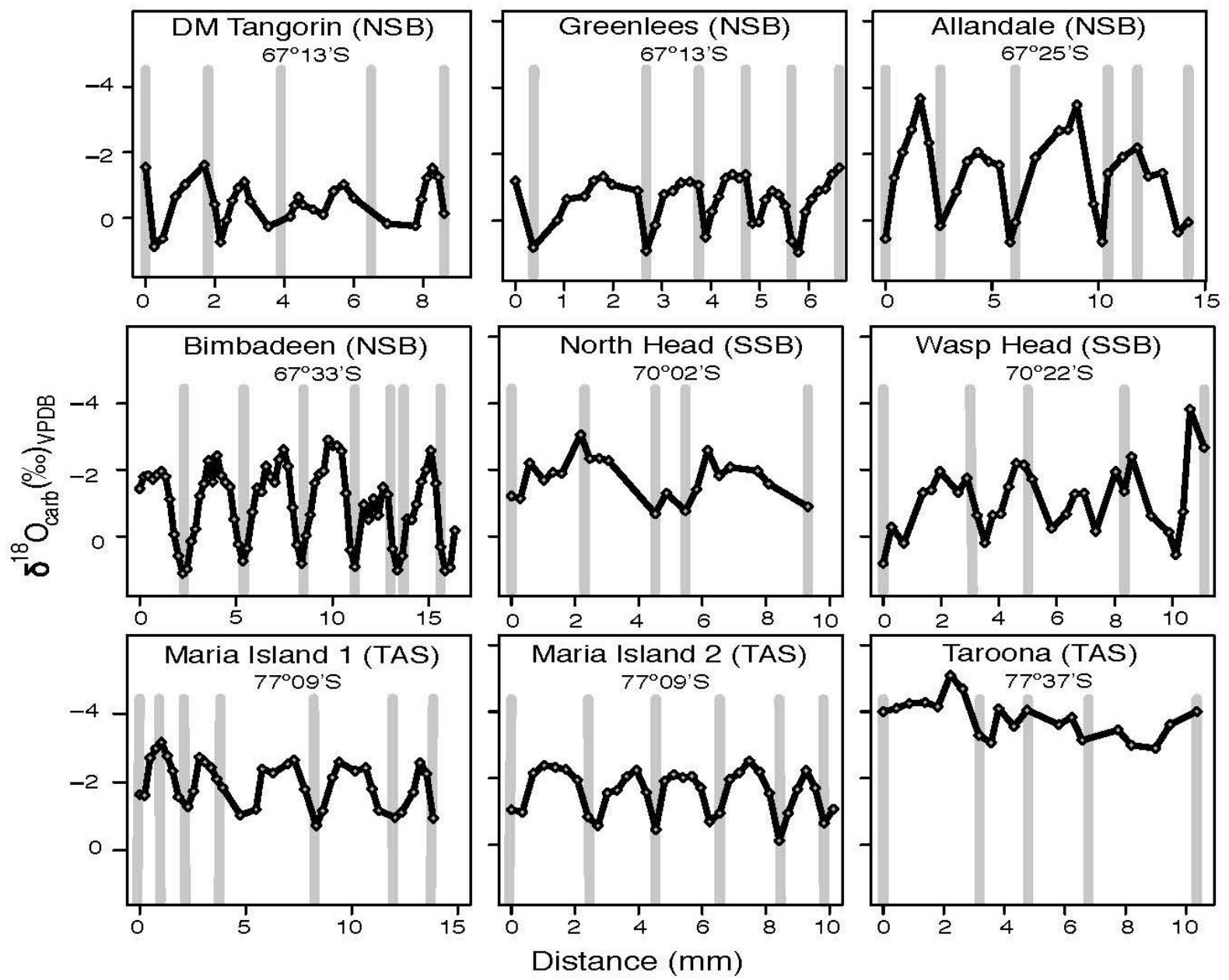

302

303

304

305

306

307

308 months. Carbon isotope values show substantially less variation within specimens, a weak tendency to co-vary with oxygen isotope values along the accretionary axis, and hover near the 
310 published values of around $+5.5 \%$ o for the early Permian open ocean (Grossman et al., 2008;

311 Mii et al., 1997; Mii et al., 2012; Veizer et al., 1999; Zeng et al., 2012), with shell means ranging

312 from +4.03 to $+6.63 \%$ o (Supplementary Figure S2).

Mean winter $\delta^{18} \mathrm{O}_{\text {carb }}$ values for each shell are computed from the most positive $\delta^{18} \mathrm{O}$

314 values within each annual cycle (3-6 winters per shell), mean summer values from the most

315 negative (2-6 summers per shell), and seasonal range from the mean difference between all

316 adjacent summer-winter pairs (Supplemental Table S2). Winter shell values decrease with

317 increasing latitude $\left(r^{2}=0.60\right.$; Figure $\left.7 A\right)$, ranging from a mean of $0.59 \pm 0.38$ in the NSB to -0.72

$318 \pm 0.35$ in Tasmania. There is no latitudinal trend in summer values (NSB average $=-1.84 \pm$

$3190.82 \%$; SSB $=-2.67 \pm 0.68 \%$; Tasmania $=-2.47 \pm 0.27 \%$ o), and the range in summer shell

320 values decreases poleward (Figure 7B). The seasonal range in $\delta^{18} \mathrm{O}$ values, therefore, generally

321 decreases with increasing latitude, but the trend is not without exception, as summer $\delta^{18} \mathrm{O}$

322 values are more variable among locations.

323

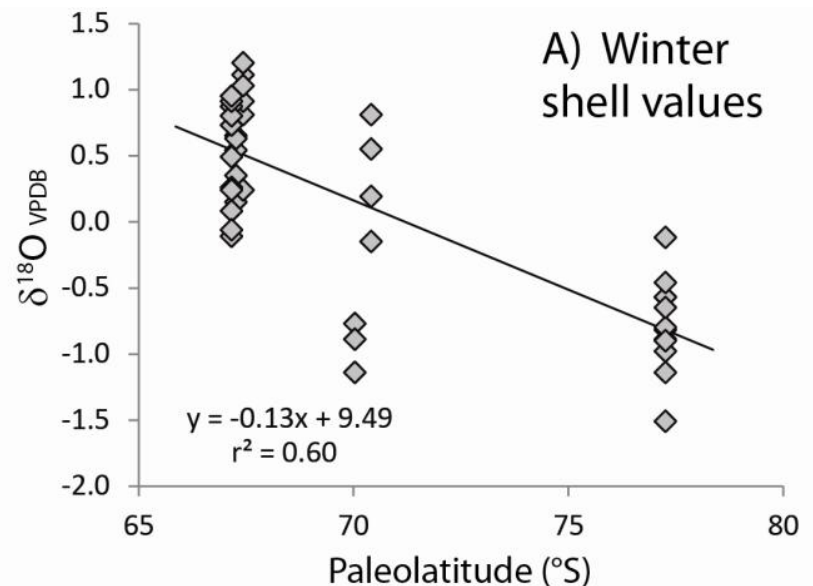

Paleolatitude ( $\left.{ }^{\circ} \mathrm{S}\right)$

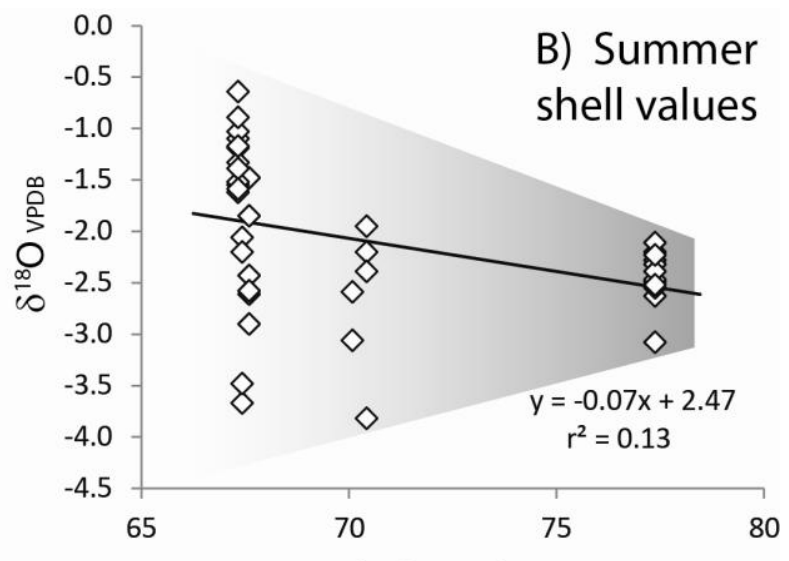

Paleolatitude ( $\left.{ }^{\circ} \mathrm{S}\right)$

Figure 7. $\delta^{18} \mathrm{O}$ values corresponding to each winter $(A)$ and summer $(B)$ season of each shell, plotted by paleolatitude. Winter shell carbonate is isotopically more negative at higher paleolatitudes. Summer values are more variable at lower latitudes, suggesting greater and 
more spatially variable contributions of meltwater during the summers. See Supplemental Table S1 for these values.

\section{Discussion}

7.1 Primary signal or diagenesis?

Critical to any paleoenvironmental interpretation based on stable oxygen isotope data is the ability to establish whether $\delta^{18} \mathrm{O}_{\text {carb }}$ values are primary and have not been altered during diagenesis. Shell microtextures are the first line of defense in an argument for unaltered materials, but dissolution and reprecipitation under some diagenetic conditions can retain original textures with a high degree of fidelity (Budd and Hiatt, 1993; Towe and Hemleben, 1976; Turekian and Armstrong, 1961). Concentrations of Fe and Mn are more typically used to investigate alteration of marine carbonates (Brand, 2004; Brand et al., 2003; Grossman, 2012; Grossman and Mii, 1996; Popp et al., 1986). Fe and Mn are often enriched during diagenesis due to the tendency for those elements to be present at higher concentrations in pore water under anoxic conditions. A range of threshold values for Fe and Mn concentrations in brachiopod and/or bivalve calcite have been proposed by numerous authors above which diagenetic alteration is to be suspected; in this study, we adopt conservative values of 300ppm Mn and 1,000ppm Fe based on observed concentrations in modern calcitic shells (Brand et al., 2003; Morrison and Brand, 1986). It should be noted that concentrations of Fe in modern shells are influenced by other factors (Cravo et al., 2007; Morrison and Brand, 1986), and moderately elevated concentrations do not necessarily indicate alteration. Beyond these, low stable isotope values themselves can also suggest alteration by meteoric waters, with oxygen being more sensitive to alteration by meteoric fluids than carbon (Knauth and Kennedy, 2009; 
353 Lohmann, 1988). Many otherwise pristine shells with minimal Fe or Mn from the Paleozoic

354 nevertheless yield surprisingly depleted $\delta^{18} \mathrm{O}_{\text {carb }}$ values (Brand, 2004; Giles, 2012; Veizer et al.,

355 1999; Veizer et al., 1997). The observed trend toward more negative $\delta^{18} \mathrm{O}_{\text {carb }}$ values with

356 increasing age has led some to suggest secular change in the oxygen isotopic composition of

357 the world oceans (Veizer et al., 1997), but this is still a contentious hypothesis (Grossman, 2012;

358 Jaffrés et al., 2007).

$359 \quad$ Eurydesma shell textures are consistent with those observed in living bivalves (Carter

360 and Stehli, 1980)(Figure 4), and samples of umbonal calcite exhibit Mn and Fe concentrations

361 well within the range of modern calcitic bivalves and below our thresholds for alteration (Figure

362 5). Samples from clearly secondary carbonate are significantly elevated in both elements in

363 comparison to shell concentrations (Figure 5). Oxygen isotope values are clustered in the most

364 positive portion of the range of published Permian values for both bivalves and non-

365 luminescent brachiopods (Figure 8, Supplemental Figure S3), consistent with primary values.

366 Clear seasonal variation associated with growth banding is present in all but one specimen (that

367 from the Derwent River at Taroona, Tasmania), also arguing for the retention of primary

368 compositions. It is therefore unlikely that diagenetic alteration has been significant. The

369 specimen from Taroona was collected from a unit intruded by a nearby Jurassic dolerite sill

370 (Supplementary Information), suggesting a potential explanation for the more negative oxygen

371 isotope values and lack of obvious seasonal cycles in this one shell. We do not consider it

372 further in this analysis.

373

374 


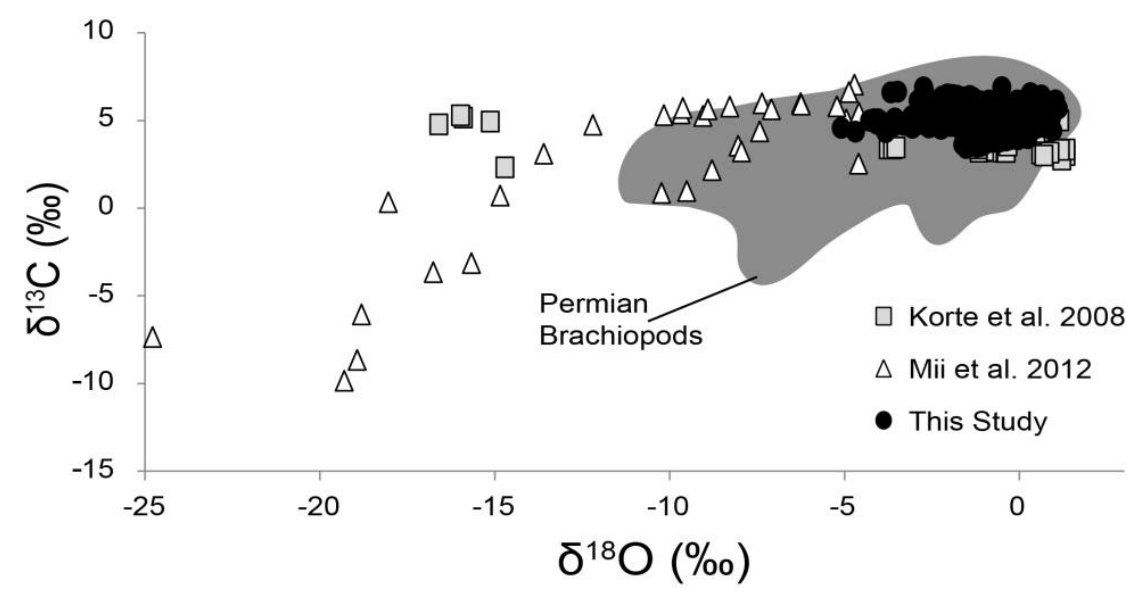

376

377

378

379

380

381

382

383

384

385

386

387

388

389

390

391

392

393

394

395

396

Figure 8. Eurydesma $\delta^{18} \mathrm{O}$ and $\delta^{13} \mathrm{C}$ values from this study (black dots) in comparison to published Permian bivalve data from Australian samples considered primary as well as those altered to varying degrees. Shaded region encloses Permian 'well-preserved' (Frank et al., 2015; Korte et al., 2008; Mii et al., 2012) and modern (Brand et al., 2003) brachiopod data. Our data cluster tightly at the most positive end of both axes, while diagenesis is expected to shift values in the negative direction (Lohmann, 1988). (Column width)

The weak tendency for $\delta^{18} \mathrm{O}$ and $\delta^{13} \mathrm{C}$ to co-vary is only apparent within individual accretionary records and disappears when all isotope data are plotted together (Supplementary Figure S3). If covariation were the result of varying degrees of meteoric diagenesis, this would not be the case (Lohmann, 1988). Interestingly, while $\delta^{18} \mathrm{O}$ and $\delta^{13} \mathrm{C}$ both exhibit regular, evidently seasonal variation within shells, the relationship between the two variables is not consistent among shells or localities, and in some cases the peaks in $\delta^{13} \mathrm{C}$ values are slightly offset from those of $\delta^{18} \mathrm{O}$. Negative covariation along the growth axis is not consistent with diagenetic alteration but is expected to result from seasonal controls on both temperature and primary production in a well-mixed water column, and spring phytoplankton production does not wait for the water to warm, potentially resulting in offset of peaks in the two variables. Positive covariation likely reflects seasonal (summer) input of $\mathrm{O}^{18}$-depleted fresh water carrying dissolved inorganic carbon derived from the decomposition of terrestrial organic matter, but 
397 could also reflect precipitation beneath a seasonally stratified water column where warm and 398 potentially $\mathrm{O}^{18}$-depleted water remains on the surface in summer but deeper waters receive $399 C^{12}$-rich organic matter from the photic zone that is remineralized at depth. Positive covariation 400 between $\delta^{18} \mathrm{O}$ and $\delta^{13} \mathrm{C}$ along a growth axis that regularly corresponds to visible growth bands is 401 not likely to result from diagenesis, though one can envision a scenario of very low water-rock 402 ratios and partial alteration concentrated in the faster-growing, less dense portions of the shell 403 between dark/translucent growth bands. More than likely though, given other indicators of 404 preservation, isotopic variation in these shells reflects primary seasonal variation in some 405 combination of temperature, production, and salinity in these nearshore deposits.

\subsection{Paleotemperatures and regional seawater composition}

409 of the early Permian ocean on the SE Australian margin, so long as a reasonable value for $410 \quad \delta^{18} \mathrm{O}_{\text {water }}$ can be obtained. Given that these early Permian bivalves were growing at a time 411 when Gondwana may still have been in part glaciated (Fielding et al., 2008c), we begin by 412 assuming that $\delta^{18} \mathrm{O}_{\text {water }}$ was close to today's global average of $0 \%$. The resulting annual 413 average temperatures, as calculated from the Epstein et al. (1953) equation for mollusk calcite 414 revised by Anderson and Arthur (1983), range from $20^{\circ} \mathrm{C}$ for the lowest latitudes to $24^{\circ} \mathrm{C}$ for the 415 highest latitudes. Not only do these temperatures suggest increasing warmth with latitude, but 416 they are far warmer than that presumed for ikaite formation $\left(0-4^{\circ} \mathrm{C}\right.$, De Lurio and Frakes, 1999

417 and stand in stark contrast with associated cold-water indicators such as diamictites, 418 glendonites, and dropstones in these sections. It therefore seems apparent that the local 
$419 \quad \delta^{18} \mathrm{O}_{\text {water }}$ at these sites was lower than $0 \%$, and that $\delta^{18} \mathrm{O}_{\text {water }}$ values likely decreased with

420 increasing latitude, so as to yield temperatures consistent with sedimentologic indicators and

421 the expected trend toward cooler temperatures with latitude that pervades on Earth today.

422 We therefore calculate local seawater $\delta^{18} \mathrm{O}$ using the isotopic compositions of shell

423 accreted during winter seasonal extremes, assuming that water temperatures were near-

424 freezing at those times. Eurydesma growth, like that of modern high-latitude bivalves, may

425 have been restricted to a consistent minimum growth temperature associated with taxon-

426 specific physiological constraints (Schöne, 2008; Weidman et al., 1994); therefore, the winter

427 temperatures recorded are likely to be about the same at each locality. Winter temperature

428 minima in the ocean do not generally fall below $-2^{\circ} \mathrm{C}$ because this is the point at which seawater

429 of typical marine salinity ( 35\%o) begins to freeze. Modern Arctic bivalves studied by Schöne et

430 al. (2005) are able to grow down to temperatures of $4^{\circ} \mathrm{C}$, and bivalves around Antarctica

431 precipitate carbonate at $0^{\circ} \mathrm{C}$ or below (Barrera et al., 1990; 1994; Sato-Okoshi and Okoshi,

432 2008). The ikaite precursor to co-occurring glendonites precipitates only at temperatures

433 below $\sim 4^{\circ} \mathrm{C}$ (Bischoff et al., 1993; Marland, 1975). Together, these observations suggest that

434 temperatures recorded by Eurydesma during the Permian Australian winter likely were in the

435 range of $0-4^{\circ} \mathrm{C}$. Solving for $\delta^{18} \mathrm{O}_{\text {water }}$ using the range of 0 to $+4^{\circ} \mathrm{C}$ and observed mean winter

436 shell compositions yields local water compositions ranging from a maximum of $-2.3 \%$ at the

437 lowest latitudes (assuming the higher precipitation temperature of $4^{\circ} \mathrm{C}$ ) to a minimum of $-5.4 \%$ o

438 at the highest (assuming the lower precipitation temperature of $0^{\circ} \mathrm{C}$; Figure 9). These values

439 are consistent with those derived from combined $\mathrm{Mg} / \mathrm{Ca}$ and oxygen isotope

440 paleothermometry on carefully chosen but undifferentiated shell carbonate in these and 
442 influence of variable amounts of summer runoff and allows for resolution of latitudinal patterns

443 that could not be discerned in this earlier study. As discussed previously, water composition is

444 likely changing seasonally through increased input of meltwater during the warmer months, but 445 we are unable to parameterize this contribution.

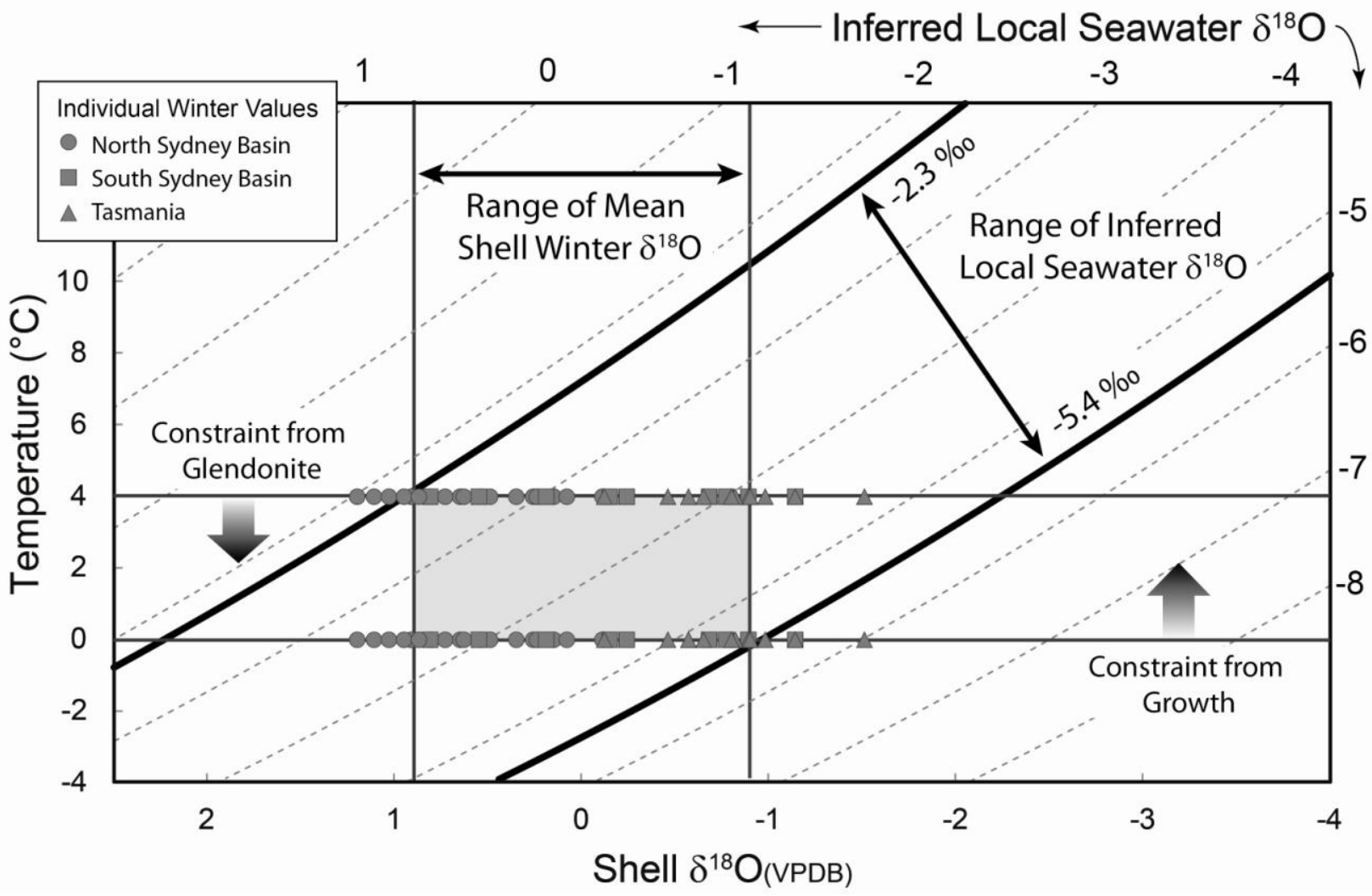

448

449

450

451

452

453

454

455

456

457
Figure 9. Best estimates of local water composition (dashed diagonal lines) off SE Australia during the Permian, bracketed by winter temperatures between 0 to $4^{\circ} \mathrm{C}$ (horizontal lines) and mean winter shell $\delta^{18} \mathrm{O}$ values (vertical lines). Pale gray symbols are individual winter values of shell carbonate from the North Sydney Basin (circles), South Sydney Basin (squares) and Maria Island, Tasmania (triangles). Local water composition therefore could have ranged from -2.3 in the north assuming temperatures of $4{ }^{\circ} \mathrm{C}$, to $\sim-5.4 \%$ in the south assuming temperatures of 0 ${ }^{\circ} \mathrm{C}$ (thick dark diagonal lines). At any single temperature of precipitation, water values vary by $\sim 1.8 \%$ across the region. ( 2 column width) 
The presence of well-preserved glendonite in the section not only constrains

459

460

461

462

463

464

465

466

467

472

473

474

475

476

477

478

479

paleotemperatures, it also offers a complementary method for estimating the composition of high-latitude seawater. Price and Nunn (2010) used the $\delta^{18} \mathrm{O}$ value of glendonite in combination with the conversion temperature from ikaite to calcite (about $8^{\circ} \mathrm{C}$; De Lurio and Frakes, 1999) to calculate the composition of Cretaceous arctic seawater, assuming pore waters only minimally differed from seawater. We applied the same approach using $\delta^{18} \mathrm{O}$ data from the ikaite replacement phase of glendonites published by Frank et al. (2008b). The average composition of 27 samples from the Wandrawandian Siltstone of the Southern Sydney Basin is $-2.50 \pm 1.8 \%$; we therefore calculate local seawater as $-4.6 \%$, within the range of seawater values independently determined from our Eurydesma calcite in this same unit. The gradient in mean seawater $\delta^{18} \mathrm{O}$ values along the SE Australian coast exhibits a negative slope of about $0.14 \%$ o per degree latitude (Figure 10 ) with an $r^{2}=0.60$, assuming a constant winter temperature of $2^{\circ} \mathrm{C}$ (midpoint between the two scenarios presented in Figure 9). Note that values calculated from the specimen at North Head, at $70^{\circ} \mathrm{S}$, fall below the regression line. This shell is younger than the others (Roadian), and removing it from the regression increases the $r^{2}$ value to .74 (as reported in Figure 10). Given the recent suggestion by Chen et al. (2013) that deglaciation began later in the Permian than previously thought, in the Kungurian, it is possible that more negative global seawater values at the time of precipitation of this shell contributed to its depletion in comparison to the trendline from other shells. The roughly $1 \%$ offset is comparable to the decrease in conodont apatite $\delta^{18} \mathrm{O}$ values between the Artinskian and Roadian reported by Chen et al. (2013) in South China, though warming temperatures also likely contributed to that drop. 


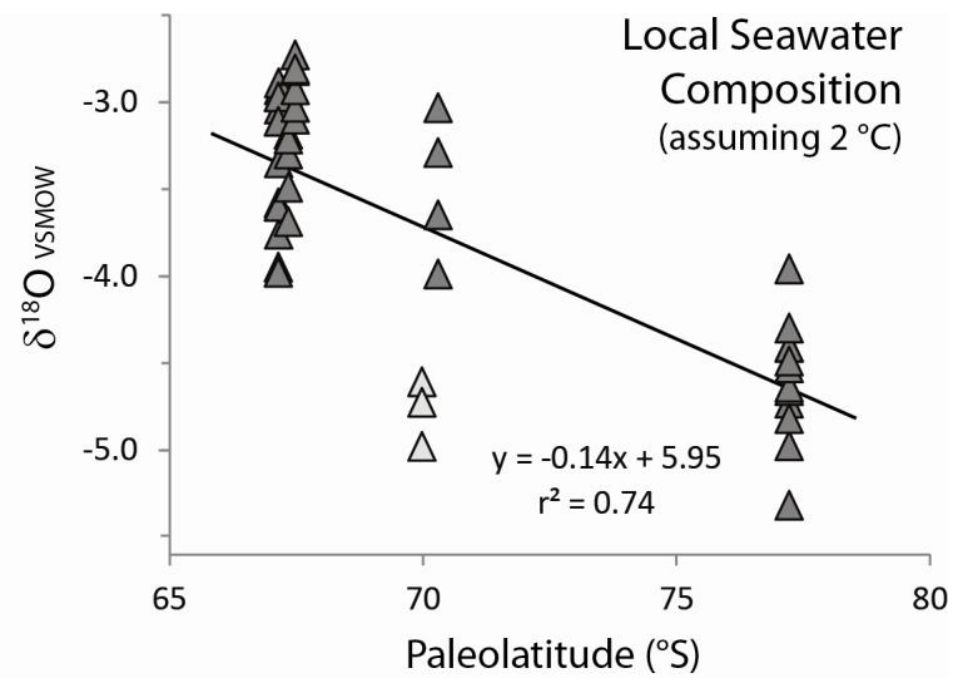

481

482

483

Figure 10. Inferred local seawater composition along the early Permian coastline of SE Australia. Values are calculated from the winter shell $\delta^{18} \mathrm{O}$ values for each paleolatitude, assuming a temperature of $2{ }^{\circ} \mathrm{C}$. Winter values presume the least amount of freshwater input, as continental waters are likely to be frozen, and therefore provide the best representation of regional seawater. Regression equation and $r^{2}$ omit the isotope values from the Wandrawandian Siltstone at North Head, in pale gray, because that sample is younger than the rest. (Column width)

7.3 Reasons for lower seawater $\delta^{18} \mathrm{O}$ values in the high latitudes

In the modern ocean, high-latitude surface-water compositions are more negative than increasing latitude (Bigg and Rohling, 2000; Bowen and Wilkinson, 2002; Craig and Gordon,

497 1965; LeGrande and Schmidt, 2006). All high-latitude, open-ocean values today exceed

$498 \quad 1.0 \%$ except in the semi-restricted Arctic Ocean, which receives isotopically depleted fresh

499 water during summer melting of polar ice and snow (Ekwurzel et al., 2001). Inferred Permian

500 local seawater values are significantly more negative, consistent with a setting that receives

501 additional input of isotopically more negative waters. The melting Gondwanan ice sheet is a 
502 likely source, as the precipitation that composed it was significantly distilled (see further

503 discussion in this section). Small amounts of meltwater combined with seawater could yield

504 depleted values without lowering salinity enough to affect the stenohaline marine shelf

505 community.

506 If the overall low values of early Permian seawater in SE Gondwana are due to

507 fresh/meltwater mixing, then the trend of increasingly negative seawater $\delta^{18} \mathrm{O}$ values toward

508 the pole cannot derive from local runoff alone unless discharge was higher at higher latitudes

509 or runoff $\delta^{18} \mathrm{O}$ was progressively more negative toward the pole. The former is unlikely, as

510 lower latitude sites should experience more melting and/or precipitation. The latter is possible

511 if the source of runoff is precipitation that fell at progressively higher latitudes and hence was

512 more distilled toward the pole. Either way however, the trend in water oxygen isotopic

513 composition is evident in the winter, when runoff should be minimal. Mixing water masses,

514 rather than local surface runoff, is perhaps a better option to explain the low and increasingly

515 negative seawater $\delta^{18} \mathrm{O}$ values with latitude.

516 Low oxygen isotope values and a similar negative gradient are seen in coastal waters off

517 SE Greenland today (Schmidt et al., 1999), suggesting that this setting might offer insights about

518 SE Australia during the Permian. The Greenland trend in water oxygen isotopic composition

519 with latitude reflects the mixing of Atlantic Ocean water with depleted Arctic Ocean water

520 transported south in the Polar Water of the East Greenland Current (Aagaard and Coachmen,

521 1968; Sutherland et al., 2009). Coriolis forces acting on this western boundary current keep the

522 coldest $\left(-1.9^{\circ} \mathrm{C}\right)$, lowest salinity $(\sim 28 \mathrm{ppt})$, and isotopically most negative $\left(\delta^{18} \mathrm{O} \sim-2.5 \%\right)$ waters

523 closest to the coastline and near the surface, and wintertime temperatures are uniformly at the 
524 freezing point above depths of $75 \mathrm{~m}$ regardless of location (Aagaard and Coachmen, 1968). $\delta^{18} \mathrm{O}$

525 values, at least during the summer (no data are available for winter), decrease to the northeast

526 along the coast (Schmidt et al., 1999; derived largely from Sutherland et al., 2009). At these

527 cold temperatures, the effect of salinity on density is stronger than the effect of temperature

528 (Sigman et al., 2004; Winton, 1997), resulting in stratification such that fresher, more negative,

529 waters remain at the surface. While Permian open-ocean surface currents are reconstructed as

530 generally flowing southward along SE Australia (Frank et al., 2015; Winguth et al., 2002), a

531 similar coast-hugging brackish boundary current could have delivered polar waters to near-

532 shore settings, with progressive dilution by isotopically more positive seawater as it flowed

533 north and entrained offshore south-flowing waters (see arrow in Figure 1A). Upwelling of cold

534 deep water associated with inferred offshore winds (Gibbs et al., 2002) has been invoked to

535 explain why the SE coast of Australia was colder than the rest of Gondwana as glaciation waned

536 (Frank et al., 2015; Jones et al., 2006). While upwelling would likely break down the observed

537 isotopic gradient along the coast, the presence of a cold polar boundary current could account

538 for both the gradient and unusually cool conditions. Crowell (1978) postulated the presence of

539 such a current driven by strong polar easterlies being deflected north along the SE margin of

540 Gondwana. North-dipping cross-bed sets in the nearshore marine Nowra Sandstone of the

541 South Sydney Basin, just upsection from the units discussed here, suggest south-to-north

542 sediment transport along the coast (Runnegar, 1984), consistent with such a current.

$543 \quad$ Inferred $\delta^{18} \mathrm{O}$ values of Permian seawater are $\sim 3 \%$ more negative than the waters off

544 Greenland today, despite similar amounts of compositional change with latitude and similar

545 inferred temperatures. Given the stenohaline nature of the Eurydesma fauna, it is unlikely that 
546 this offset is due to proportionally greater contributions of runoff to the Permian coastline than

547 Greenland sees today. More likely, Gondwanan glacier ice and meltwater were more depleted

548 in $\mathrm{O}^{18}$. The modern Antarctic ice sheet has $\delta^{18} \mathrm{O}$ values as low as $-50 \%$ (Morgan, 1982), and

549 Gondwana was an even larger polar land mass with the potential for highly depleted

550 precipitation in its interior. Assuming Permian oceans were not unlike those today and marine

551 isotope values at $\sim 65^{\circ} \mathrm{S}$ were roughly $-0.5 \%$, a mixture with a salinity of approximately 31 -

552 33ppt (roughly 5-9\% fresh water) would result from the addition of enough fresh water at -

$55350 \%$ o to yield calculated water values of -3.0 to $-5.0 \%$. If meltwater or runoff were less

554 depleted in $\mathrm{O}^{18}$, proportionally more would be needed to achieve the inferred values. Salinity

555 did not drop to the point that marine paleoecology was affected, placing an albeit poorly

556 defined cap on the amount of fresh water mixed into coastal waters. Exceeding this limit could

557 require a call for isotopically more negative global average seawater. If this were the case,

558 Cisuralian paleotemperatures previously calculated from observed $\delta^{18} \mathrm{O}_{\text {carb }}$ values would be

559 systematically too warm (e.g., see Giles, 2012).

560

561

7.4 Paleoseasonality

562

The seasonal range of $\delta^{18} \mathrm{O}_{\text {carb }}$ decreases with increasing latitude. These values can be

563 used to infer patterns in temperature seasonality on the early Permian Australian margin.

564 Given the typical attenuation of seasonal extremes by shell growth pointed out by Williams et

565 al. (1982) and addressed by Wilkinson and Ivany (2002) and Goodwin et al. (2003), these are

566 likely to be conservative estimates because the full winter portion of the seasonal signal may

567 not be represented. Because winter water temperatures are presumed to be near freezing at 
568 all localities, the decrease in the seasonal range of $\delta^{18} \mathrm{O}_{\text {carb }}$ with increasing latitude must be due 569 to a drop in summer temperatures toward the pole and/or to increased amounts of run-off at 570 the lower latitudes in the summer. Local Permian water compositions calculated from shell 571 winter $\delta^{18} \mathrm{O}$ values combined with an estimated minimum recorded temperature of $2^{\circ} \mathrm{C}$ allow 572 for an approximation of summer temperatures and hence the seasonal range of temperatures 573 recorded by each specimen, under the admittedly simplifying assumption that local $\delta^{18} \mathrm{O}_{\text {water }}$ is 574 fairly constant throughout the year. Permian shallow marine summers are generally warmer, 575 and hence seasonality is greater, at lower latitudes (Figures 6,7); North Sydney Basin summers 576 average $10.5^{\circ} \mathrm{C}$ while Tasmanian Basin summers average $7.7^{\circ} \mathrm{C}$. Summer temperatures are also 577 more variable in the north, with some years reaching temperatures as warm as $17^{\circ} \mathrm{C}$, while 578 summers span a range of only $2.2^{\circ} \mathrm{C}$ in Tasmania $\left(7.1\right.$ to $9.3^{\circ} \mathrm{C}$. These early Permian summer water temperatures, and hence seasonal ranges, are on 580 the high end of or exceed those at similar latitudes (north or south) today (World Ocean Atlas 5812009 , Locarnini et al., 2010). More than likely, increased freshwater runoff during the summers at 582 the lower latitudes is magnifying the apparent summer temperatures and seasonal 583 temperature range inferred from carbonate $\delta^{18} \mathrm{O}$ values. Nevertheless, summers warmer than 584 might be expected in SE Gondwana, given the presence of a waning ice sheet on the continent, 585 could result from the influence of a large land mass in the Southern Hemisphere at this time 586 (Crowley et al., 1986), so long as portions of the continent were ice-free and so had lower 587 albedo. Glossopterid-dominated cold-temperate floras in SE Gondwana (Rees et al., 2002) and 588 our observation of large fossil trees in the South Syndey Basin nearshore marine section 589 suggests this to be the case. Coastal temperatures such as those reported here would be more 
590 subject to seasonal continental albedo effects than open ocean temperatures. The degree to

591 which ${ }^{18} \mathrm{O}$-depleted freshwater runoff is augmenting calculated summer temperatures is not 592 possible to constrain at this time.

593

594

595

596

597

598

599

600

601

602

603

604

605

606

607

608

609

610

611

\subsection{Perspectives on high-latitude settings}

Our isotope-based temperature estimates are consistent with a cold, but not frigid, polar setting. Glendonites and dropstones require freezing winters and floating ice, but the presence of driftwood in the section indicates trees on nearby land and hence summers that reach or exceed $\sim 10^{\circ} \mathrm{C}$ (Rees et al., 2002). Today's Antarctic coasts, with water temperatures hovering near zero year-round, is therefore not the best analog for the Cisuralian of Australia, despite similar latitudes. A comparison with somewhat warmer periods of Antarctica's glaciated history, such as the early-middle Miocene (Burdigalian) when summer water temperatures may have been as warm as $11^{\circ} \mathrm{C}$ (Feakins et al., 2012; Lavelle, 2001; Shevenell et al., 2008; Warny et al., 2009), is perhaps more appropriate. During this interval, Antarctic ice volume varied significantly, dropping to as little as $25 \%$ of the present East Antarctic ice sheet (Pekar and DeConto, 2006), and woody plants reappeared on the continent (Warny et al., 2009), not unlike that inferred for the mid-Cisuralian.

Aspects of the Australian marine fauna, too, are better interpreted in this light. Ever since Etheridge and Dun (1910) carried out the first in-depth study of Eurydesma, the massively thickened shells have seemed anomalous for circumpolar conditions: "The umbonal region of the valves in Eurydesma is of extraordinary thickness, and it is interesting to note, as Mr. Charles Hedley has pointed out, that all recent bivalves comparable in valve thickness occur in 
612 tropical waters" (Etheridge and Dun, 1910, p. ix). In addition, several species of eastern

613 Australian bivalves (including Eurydesma), gastropods, and brachiopods are relative giants for

614 Paleozoic seas even at lower latitudes. Eurydesma grew to a maximum size of $15 \mathrm{~cm}$, with

615 umbones up to $6 \mathrm{~cm}$ thick. The unrelated but co-occurring anomalodesmatan bivalve Myonia

616 corrugata achieved similar sizes and valve thicknesses (Supplemental Figure S4B; Runnegar,

617 1979). One specimen of the inoceramiform pteriomorph bivalve, Aphanaia de Koninck, is 41.5

$618 \mathrm{~cm}$ in length, and 18 species of bivalves, gastropods and brachiopods were larger than $10 \mathrm{~cm}$ in

619 size (Runnegar, 1984, fig. 2). Modern polar bivalves tend to be small and thin-shelled (e.g.

620 www.arcodiv.org/seabottom/Bivalves.html). If body size is expressed as $\log _{2}(\mathrm{SQRT} L * H)$,

621 where $\mathrm{L}$ and $\mathrm{H}$ are shell lengths and heights (Krug et al., 2010), then 23 eastern Australian

622 Permian shells (bivalves, brachiopods, gastropods) exceeded a $\log _{2}$ size of 6, compared with

623 only a single extant species of Antarctic bivalve (Krug et al., 2010, fig. 3). Likewise, modern

624 polar taxa are drab in color, while at least three of the Australasian Permian species, including

625 E. cordatum, were brightly colored (Percival et al., 2012, fig. 7; Runnegar, 1979, fig. 1B;

626 Waterhouse, 1963, pl. 102 fig. 4)(Supplemental Figure S4D). To the degree that temperature is

627 responsible for the differences in size and color, these observations together further suggest

628 that the early Permian high southern latitudes were not as cold as those today. Indeed the

629 Miocene again presents a reasonable analog, as some Miocene Antarctic bivalves are strikingly

630 similar to common Permian ones [e.g., Miocene Australochlamys anderssoni (Beu and Taviani,

631 2014, fig. 3D) and Permian Deltopecten mitchelli (Waterhouse, 1987, pl. 4, fig. 14)].

632

633 8. Conclusions 
Although a number of authors have attempted to estimate Permian temperatures from

635

636

637

638

639

640

641

642

643

644

645

646

647

648

649

650

651

652

653

654

655

oxygen isotope values of biogenic calcite, all share the difficulty of estimating water

compositions in their chosen settings. We present an alternative approach that relies on

independent evidence for temperature derived from the sedimentary record and on seasonally

resolved isotope data preserved in accretionary shell carbonate. Inferred freezing winter

minimum temperatures and measured carbonate oxygen isotope values allow determination of

early Permian water composition along the SE coast of Australia, revealing a $1.3 \%$ decrease

over $\sim 10^{\circ}$ of increasing paleolatitude, a trend similar to that off of the coast of Greenland

today. Calculated water values are significantly more negative, reflecting the contribution of

isotopically more negative runoff from the Gondwanan continent. It should be possible to use

this gradient to better estimate $\delta^{18} \mathrm{O}$-derived temperatures from previously recovered

specimens at similar paleolatitudes along SE Australia. Equatorward, there should be a point

where marine wintertime carbonate $\delta^{18}$ O begins to decrease, marking the point where

warming temperatures, rather than decreasing polar runoff, become the dominant influence on

the gradient. Improved high-resolution sampling across a wider range of Permian

paleolatitudes and geographical locations, as well as progress toward independent controls on

paleotemperatures, will help to better constrain Permian Ocean chemistry and climates.

\section{Acknowledgements}

Dan Petrizzo is gratefully acknowledged for collaboration on the field portion of this

study. Special thanks go to Peter and Kaye Makeig (Bimbadeen), Warwick Denshire

(Greenlees), Steve Hall, Simone Meakin, and Ian Percival (Geological Survey of New South 
656 Wales), Matthew Billings (Hunter 8 Alliance), Phil Smart (Mollymook), Mike Clarke (Taroona),

657 Trevor and Pat Hanigan (Derwent Estate Wines), Michael Comfort (Primary Industries, Parks,

658 Water and Environment, Tasmania), and Pete Lingard (Maria Island National Park) for

659 assistance, for access to the Allandale project, the DM Tangorin 1 core, and field sites, and for

660 permissions to sample and collect. We thank Paul Tomascak at SUNY-Oswego for help with ICP-

661 MS work, David Linsley at Colgate University for preparing the thin sections, Jack Hietpas and

662 Melissa Hicks for help interpreting textures, Maddie O’Connor for help in sampling, and Artem

663 Kouchinsky for some isotopic analyses carried out at UCLA in the E.D. Young Laboratory. All

664 other stable isotope analyses were done at the Keck Paleoenvironmental \& Environmental

665 Stable Isotope Laboratory at the University of Kansas. This work benefited from meaningful

666 discussions with Scott Samson, Bruce Wilkinson, and Paul Tomascak, and from substantive and

667 thoughtful comments by three anonymous reviewers. Research was supported by the

668 Department of Earth Sciences at Syracuse University and a Stephen Jay Gould Research Grant

669 from the Paleontological Society (to JAB), the American Federation of Mineralogical Societies

670 and the College of Arts and Sciences at SU (to LCl), the NASA Astrobiology Institute and the

671 Committee on Research at UCLA (to BR). Collections used in this study were assembled at the

672 University of New England, Armidale and UCLA by BR with financial assistance from the

673 Australian Research Council, Dolf Seilacher (Tübingen), and the U.S. National Science

674 Foundation.

675

676

677

678

679 Beard et al. Supplementary Information.doc; Beard et al suppl data file.xlsx 
681

682

683

684

685

686

687

688

689

690

691

692

693

694

695

696

697

698

699

700

701

702

703

704

705

706

707

708

709

710

711

712

713

714

715

Aagaard, K., Coachmen, L.K., 1968. The East Greenland Current North of Denmark Strait: Part 1. Arctic 21, 181-200.

Anderson, T.F., Arthur, M.A., 1983. Stable isotopes of oxygen and carbon and their application to sedimentologic and paleoenvironmental problems, in: Arthur, M.A., Anderson, T.F., Kaplan, I.R., Veizer, J., Land, L.S. (Eds.), Stable Isotopes in Sedimentary Geology. SEPM Short Course No. 10, Tulsa, OK, pp. 1151.

Angiolini, L., Jadoul, F., Leng, M.J., Stephenson, M.H., Rushton, J., Chenery, S., Crippa, G., 2009. How cold were the Early Permian glacial tropics? Testing sea-surface temperature using oxygen isotope composition of rigorously screened brachiopod shells. Journal of the Geological Society of London 166, 933-945.

Barrera, E., Tevesz, M.J.S., Carter, J.G., 1990. Variations in oxygen and carbon isotopic composition and microstructure of the shell of Adamussium colbecki (Bivalvia). Palaios 5, 149-159.

Barrera, E., Tevesz, M.J.S., Carter, J.G., McCall, P.L., 1994. Oxygen and carbon isotopic composition and shell microstructure of the bivalve Laternula elliptica from Antarctica. Palaios 9, 275-287.

Bembrick, C.S., Holmes, G.G., 1976. An interpretation of the subsurface geology of the Nowra-Jervis Bay area. Geological Survey of New South Wales Record 18, 5-68.

Beu, A., Taviani, M., 2014. Early Miocene Mollusca from McMurdo Sound, Antarctica (Andrill 2A drill core), with a review of Antarctic Oligocene and Neogene Pectinidae (Bivalvia). Palaeontology 57, 299342.

Bieler, R., Mikkelsen, P.M., Collins, T.M., Glover, E.A., González, V.L., Graf, D.L., Harper, E.M., Healy, J., Kawauchi, G.Y., Sharma, P.P., Staubach, S., Strong, E.E., Taylor, J.D., Tëmkin, I., Zardus, J.D., Clark, S., Guzmán, A., Mclntyre, E., Sharp, P., Giribet, G., 2014. Investigating the Bivalve Tree of Life - an exemplar-based approach combining molecular and novel morphological characters. Invertebrate Systematics 28, 32. 10.1071/is13010.

Bigg, G.R., Rohling, E.J., 2000. An oxygen isotope data set for marine water. Journal of Geophysical Research 105, 8527-8535.

Bischoff, J.L., Fitzpatrick, J.A., Rosenbauer, R.J., 1993. The solubility and stabilization of ikaite $\left(\mathrm{CaCO}_{3} \bullet 6 \mathrm{H}_{2} \mathrm{O}\right)$ from $0^{\circ}$ to $25^{\circ} \mathrm{C}$ : environmental and paleoclimatic implications for thinolite tufa. Journal of Geology 101, 21-33.

Black, L.P., Kamo, S.L., Williams, I.S., Mundil, R., Davis, D.W., Korsch, R.L., Foudoulis, C., 2003. The application of SHRIMP to Phanerozoic geochronology; a critical appraisal of four zircon standards. Chemical Geology 200, 171-188.

Bowen, G.J., Wilkinson, B.H., 2002. Spatial distribution of $\delta^{18} \mathrm{O}$ in meteoric precipitation. Geology 30, 315-318. 
Brand, U., 2004. Carbon, oxygen and strontium isotopes in Paleozoic carbonate components: an evaluation of original seawater-chemistry proxies. Chemical Geology 204, 23-44.

Brand, U., Logan, A., Hiller, N., Richardson, J., 2003. Geochemistry of modern brachiopods: applications and implications for oceanography and paleoceanography. Chemical Geology 198, 305-334.

Brand, U., Posenato, R., Came, R., Affek, H., Angiolini, L., Azmy, K., Farabegoli, E., 2012. The end-Permian mass extinction: A rapid volcanic $\mathrm{CO}_{2}$ and $\mathrm{CH}_{4}$ climatic catastrophe. Chemical Geology 322-323, 121-144. 10.1016/j.chemgeo.2012.06.015.

Brand, U., Tazawa, J., Sano, H., Azmy, K., Lee, X., 2009. Is mid-late Paleozoic ocean-water chemistry coupled with epeiric seawater isotope records? Geology 37, 823-826.

Briggs, D.J.C., 1998. Permian Productina and Strophalosiidina from the Sydney-Bowen Basin and New England Orogen: systematics and biostratigraphic significance. Association of Australasian Palaeontologists Memoir 19, 1-258.

Budd, D.A., Hiatt, E.E., 1993. Mineralogical stabilization of high-magnesium calcite: geochemical evidence for intracrystal recrystallization within Holocene porcellaneous foraminifera. Journal of Sedimentary Petrology 63, 261-274.

Came, R.E., Brand, U., Affek, H.P., 2014. Clumped isotope signatures in modern brachiopod carbonate. Chemical Geology 377, 20-30. 10.1016/j.chemgeo.2014.04.004.

Carter, J.G., Stehli, F.G., 1980. Environmental and biological controls of bivalve shell mineralogy and microstructure, in: Rhoads, D.C., Lutz, R.A. (Eds.), Skeletal Growth of Aquatic Organisms: Biological Records of Environmental Change. Plenum Press, New York, pp. 69-113.

Cawood, P.A., Leitch, E.C., Merle, R.E., Nemchin, A.A., 2012. Orogenesis without collision: stabilizing the Terra Australis acceretionary orogen, eastern Australia. Geological Society of America Bulletin 123, 2240-2255.

Chauvaud, L., Lorrain, A., Dunbar, R.B., Paulet, Y.-M., Thouzeau, G., Jean, F., Guarini, J.-M., Mucciarone, D., 2005. Shell of the Great Scallop Pecten maximusas a high-frequency archive of paleoenvironmental changes. Geochemistry, Geophysics, Geosystems 6, n/a-n/a. 10.1029/2004gc000890.

Chen, B., Joachimski, M.M., Shen, S.-z., Lambert, L.L., Lai, X.-I., Wang, X.-d., Chen, J., Yuan, D.-X., 2013. Permian ice volume and palaeoclimate history: Oxygen isotope proxies revisited. Gondwana Research 24, 77-89. 10.1016/j.gr.2012.07.007.

Cisterna, G.A., Shi, G.R., 2014. Lower Permian brachiopods from Wasp Head Formation, Sydney Basin, southeastern Australia. Journal of Paleontology 88, 531-544.

Claoué-Long, J.C., Korsch, R.J., 2003. Numerical time measurement in the DM Tangorin DDH1 drillhole, in: Facer, R.A., Foster, C.B. (Eds.), Geology of the Cranky Corner Basin. Geological Survey of New South Wales Coal and Petroleum Bulletin 4, pp. 179-205. 
Clapham, M.E., James, N.P., 2008. Paleoecology of Early-Middle Permian marine communities in Eastern Australia: response to global climate change in the aftermath of the Late Paleozoic Ice Age. Palaios 23, 738-750. 10.2110/palo.2008.p08-022r.

Clarke, M.J., 1969. Preliminary notes on the occurrence of the Allandale and Ulladulla faunas in Tasmania. Technical Reports, Department of Mines, Tasmania 13, 128-138.

Clarke, M.J., 1989. Lower Parmeener Supergroup, in: Burrett, C.F., Martin, E.L. (Eds.), Geology and Mineral Resources of Tasmania: Geological Society of Australia Special Publication 15, pp. 295-309.

Clarke, M.J., 1992. Hellyerian and Tamarian (Late Carboniferous - Lower Permian) invertebrate faunas from Tasmania. Tasmanian Geological Survey Bulletin 69, 1-52.

Clarke, M.J., Baillie, P.W., 1984. Geological atlas 1:50 000 series. Sheet 77(8512N), Maria. Tasmanian Geological Survey Explanatory Report, 1-39.

Clarke, M.J., Farmer, N., 1982. Late Paleozoic cold-water carbonate sedimentation in TasmaniaDiscussion. Journal of Sedimentary Petrology 52, 682-683.

Craig, H., Gordon, L.I., 1965. Deuterium and oxygen 18 variations in the ocean and the marine atmosphere. Marine Geochemistry 3, 277-374.

Cravo, A., Foster, P., Almeida, C., Company, R., Cosson, R.P., Bebianno, M.J., 2007. Metals in the shell of Bathymodiolus azoricus from a hydrothermal vent site on the Mid-Atlantic Ridge. Environment international 33, 609-615. 10.1016/j.envint.2007.01.002.

Crowell, J.C., 1978. Gondwanan glaciation, cyclothems, continental positioning, and climate change. American Journal of Science 278, 1345-1372. 10.2475/ajs.278.10.1345.

Crowell, J.C., Frakes, L.A., 1971. Late Paleozoic glaciation: Part IV, Australia. Geological Society of America Bulletin 82, 2515-2540.

Crowley, T.J., Short, D.A., Mengel, J.G., North, G.R., 1986. Role of seasonality in the evolution of climate during the last 100 million years. Science $231,579-584$.

De Lurio, J.L., Frakes, L.A., 1999. Glendonites as a paleoenvironmental tool: Implications for early Cretaceous high latitude climates in Australia. Geochimica et Cosmochimica Acta 63, 1039-1048.

Degeling, P.R., Runnegar, B., 1979. New Early Permian fossil localities at Halls Peak and their regional significance. Geological Survey of New South Wales Quarterly Notes 36, 10-13.

Dickins, J.M., 1970. Correlation and subdivision of the Permian of western and eastern Australia. Bureau of Mineral Resources, Geology and Geophysics, Australia Bulletin 116, 17-27.

Dickins, J.M., 1985. Late Palaeozoic glaciation. Bureau of Mineral Resources Journal of Geology and Geophysics 9, 163-169.

Dickins, J.M., 1996. Problems of a late Palaeozoic glaciation in Australia and subsequent climate in the Permian. Palaeogeography, Palaeoclimatology, Palaeoecology 125, 185-197. 
Dickins, J.M., Sullivan, W.A., 1979. A glacial moraine in the Permian Lochinvar Formation of the Sydney Basin, New South Wales. Search 10, 190-191.

Ekwurzel, B., Schlosser, P., Mortlock, R.A., Fairbanks, R.G., Swift, J.H., 2001. River runoff, sea ice meltwater, and Pacific water distribution and mean residence times in the Arctic Ocean. Journal of Geophysical Research 106, 9075-9092.

Epstein, S., Buchsbaum, H.S., Lowenstam, H.A., Urey, H.C., 1953. Revised carbonate-water isotopic temperature scale. Bulletin of the Geological society of America 64, 1315-1326.

Etheridge, R.M., Dunn, W.S., 1910. A monograph on the Permo-Carboniferous invertebrata of New South Wales. Vol. 2 - Pelecypoda, Part 2 - Eurydesma. Memoirs of the Geological Survey of New South Wales, Palaeontology 5, 41-75.

Eyles, N., Eyles, C.H., Gostin, V.A., 1997. Iceberg rafting and scouring in the Early Permian Shoalhaven Group of New South Wales, Australia: Evidence of Heinrich-like events? Palaeogeography, Palaeoclimatology, Palaeoecology 136, 1-17. http://dx.doi.org/10.1016/S0031-0182(97)00094-1.

Feakins, S.J., Warny, S., Lee, J.-E., 2012. Hydrologic cycling over Antarctica during the middle Miocene warming. Nature Geosci 5, 557-560. http://www.nature.com/ngeo/journal/v5/n8/abs/ngeo1498.html\#supplementary-information.

Fielding, C.R., Bann, K.L., MacEachern, J.A., Tyes, S.C., Jones, B.G., 2006. Cyclicity in the nearshore marine to coastal, Lower Permian, Pebbley Beach Formation, southern Sydney Basin, Australia: a record of relative sea-level fluctuations at the close of the Late Palaeozoic Gondwanan ice age. Sedimentology 53, 435-463.

Fielding, C.R., Frank, T.D., Birgenheier, L.P., Rygel, M.C., Jones, A.T., Roberts, J., 2008a. Stratigraphic imprint of the Late Palaeozoic Ice Age in eastern Australia: a record of alternating glacial and nonglacial climate regime. Journal of the Geological Society of London 165, 129-140.

Fielding, C.R., Frank, T.D., Birgenheier, L.P., Rygel, M.C., Jones, A.T., Roberts, J., 2008b. Stratigraphic record and facies associations of the late Paleozoic ice age in eastern Australia (New South Wales and Queensland), in: Fielding, C.R., Frank, T.D., Isbell, J.L. (Eds.), Resolving the Late Paleozoic Ice Age in Time and Space: Geological Society of America Special Paper 441, pp. 41-57.

Fielding, C.R., Frank, T.D., Isbell, J., 2008c. The late Paleozoic ice age - a review of current understanding and synthesis of global climate patterns, in: Fielding, C.R., Frank, T.D., Isbell, J.L. (Eds.), Resolving the Late Paleozoic Ice Age in Time and Space: Geological Society of America Special Paper 441, pp. 343-354.

Fielding, C.R., Frank, T.D., Isbell, J.L., Henry, L.C., Domack, E.W., 2010. Stratigraphic signature of the late Palaeozoic Ice Age in the Parmeener Supergroup of Tasmania, SE Australia, and inter-regional comparisons. Palaeogeography, Palaeoclimatology, Palaeoecology 298, 70-90.

Frank, T.D., Birgenheier, L.P., Montanez, I.P., Fielding, C.R., Rygel, M.C., 2008a. Late Paleozoic climate dynamics revealed by comparison of ice-proximal stratigraphic and ice-distal isotopic records, in: Fielding, C.R., Frank, T.D., Isbell, J. (Eds.), Resolving the Late Paleozoic Ice Age in Time and Space, GSA Special Paper 144, pp. 331-342. 
Frank, T.D., Pritchard, J.M., Fielding, C.R., Mory, A.J., 2012. Cold-water carbonate deposition in a highlatitude, glacially influenced Permian seaway (Southern Carnarvon Basin, Western Australia). Australian Journal of Earth Sciences 59, 479-494. 10.1080/08120099.2012.672932.

Frank, T.D., Shultis, A.I., Fielding, C.R., 2015. Acme and demise of the late Palaeozoic ice age: A view from the southeastern margin of Gondwana. Palaeogeography, Palaeoclimatology, Palaeoecology 418, 176-192. 10.1016/j.palaeo.2014.11.016.

Frank, T.D., Thomas, S.G., Fielding, C.R., 2008b. On using carbon and oxygen isotope data from glendonites as paleoenvironmental proxies: a case study from the Permian System of eastern Australia. Journal of Sedimentary Research 78, 713-723.

Gibbs, M.T., Rees, P.M., Kutzbach, J.E., Ziegler, A.M., Behling, P.J., Rowley, D., 2002. Simulations of Permian climate and comparisons with climate-sensitive sediments. Journal of Geology 2002, 33-55.

Giles, P.S., 2012. Low-latitude Ordovician to Triassic brachiopod habitat temperatures (BHTs) determined from $\delta 180$ [brachiopod calcite]: A cold hard look at ice-house tropical oceans. Palaeogeography, Palaeoclimatology, Palaeoecology 317-318, 134-152. 10.1016/j.palaeo.2012.01.002.

Goodwin, D.H., Schone, B.R., Dettman, D.L., 2003. Resolution and fidelity of oxygen isotopes as paleotemperature proxies in bivalve mollusk shells: Models and observations. Palaios 18, 110-125.

Gostin, V.A., Herbert, C., 1973. Stratigraphy of Upper Carboniferous and Lower Permian sequence, southern Sydney Basin. Journal of the Geological Society of Australia 20, 49-70.

Gröcke, D.R., Gillikin, D.P., 2008. Advances in mollusc sclerochronology and sclerochemistry: tools for understanding climate and environment. Geo-Marine Letters 28, 265-268. 10.1007/s00367-008-0108-4.

Grossman, E.L., 2010. The oxygen isotope record for the Paleozoic: The case for constant seawater $\delta^{18} O$ and warm early-mid Paleozoic oceans. Geological Society of America Abstracts with Programs 42, 513.

Grossman, E.L., 2012. Applying oxygen isotope paleothermometry in deep time, in: Ivany, L.C., Huber, B.T. (Eds.), Reconstructing Earth's Deep-Time Climate. Paleontological Society Papers, pp. 39-67.

Grossman, E.L., Mii, H.-S., 1996. Chemical variation in Pennsylvanian brachiopod shells--diagenetic, taxonomic, microstructural, and seasonal effects. Journal of Sedimentary Research 66, 1011-1022.

Grossman, E.L., Mii, H.-S., Yancey, T.E., 1993. Stable isotopes in Late Pennsylvanian brachiopods from the United States: Implications for Carboniferous paleoceanography. Geological Society of America Bulletin 105, 1284-1296.

Grossman, E.L., Yancey, T.E., Jones, T.E., Bruckschen, P., Chuvashov, B., Mazzullo, S.J., Mii, H.-S., 2008. Glaciation, aridification, and carbon sequestration in the Permo-Carboniferous: the isotopic record from low latitudes. Palaeogeography, Palaeoclimatology, Palaeoecology 268, 222-233.

Isbell, J.L., Henry, L.C., Reid, C.M., Fraiser, M.L., 2012. Sedimentology and palaeoecology of lonestonebearing mixed clastic rocks and cold-water carbonates of the Lower Permian Basal Beds at Fossil Cliffs, Maria Island, Tasmania (Australia): Insight into the initial decline of the late Palaeozoic ice age. Geological Society, London, Special Publications 376, 307-341. 10.1144/sp376.2. 
Ivany, L.C., 2012. Reconstructing paleoseasonality from accretionary skeletal carbonates: challenges and opportunities, in: Ivany, L.C., Huber, B.T. (Eds.), Reconstructing Earth's Deep-Time Climate. The Paleontological Society Papers, pp. 133-165.

Ivany, L.C., Runnegar, B., 2010. Early Permian seasonality from bivalve $\delta^{18} \mathrm{O}$ and implications for the oxygen isotopic composition of seawater. Geology 38, 1027-1030. 10.1130/g31330.1.

Jaffrés, J.B.D., Shields, G.A., Wallmann, K., 2007. The oxygen isotope evolution of seawater: A critical review of a long-standing controversy and an improved geological water cycle model for the past 3.4 billion years. Earth Science Reviews 83, 83-122.

Jones, A.T., Frank, T.D., Fielding, C.R., 2006. Cold climate in the eastern Australian mid to late Permian may reflect cold upwelling waters. Palaeogeography, Palaeoclimatology, Palaeoecology 237, 370-377.

Jones, D.S., Quitmyer, I.R., 1996. Marking time with bivalve shells: oxygen isotopes and season of annual increment formation. Palaios 11, 340-346.

Kirby, M.X., Soniat, T.M., Spero, H.J., 1998. Stable isotope sclerochronology of Pleistocene and Recent oyster shells (Crassotrea virginica). Palaios 13, 560-569.

Klein, R.T., Lohmann, K.C., Thayer, C.W., 1996. Bivalve skeletons record sea-surface temperature and $\mathrm{d} 180$ via $\mathrm{Mg} / \mathrm{Ca}$ and ${ }^{18} \mathrm{O} /{ }^{16} \mathrm{O}$ ratios. Geology $24,415-418$.

Klootwijk, C., 2009. Sedimentary basins of eastern Australia: paleomagnetic constraints on geodynamic evolution in a global context Australian Journal of Earth Sciences 56, 273-308.

Knauth, L.P., Kennedy, M.J., 2009. The late Precambrian greening of the Earth. Nature 460, 728-732.

Korte, C., Jasper, T., Kozur, H.W., Veizer, J., 2005. $\delta^{18} \mathrm{O}$ and $\delta^{13} \mathrm{C}$ of Permian brachiopods: a record of seawater evolution and continental glaciation. Palaeogeography, Palaeoclimatology, Palaeoecology 224, 333-351.

Korte, C., Jones, P.J., Brand, U., Mertmann, D., Veizer, J., 2008. Oxygen isotope values from highlatitudes: clues for Permian sea-surface temperature gradients and Late Palaeozoic deglaciation. Palaeogeography, Palaeoclimatology, Palaeoecology 269, 1-16.

Krug, A.Z., Jablonski, D., Roy, K., Beu, A.G., 2010. Differential extinction and the contrasting structure of polar marine faunas. PLoS One 5, e15362. 10.1371/journal.pone.0015362.

Lavelle, M., 2001. Molluscan oxygen isotope estimates of seasonality and Cenozoic Antarctic marine temperatures, in: Florindo, F., Cooper, A.K. (Eds.), The geologic record of the Antarctic ice sheet from drilling, coring and seismic studies. Quarderni di Geofisica v. 16, pp. 115-116.

LeGrande, A.N., Schmidt, G.A., 2006. Global gridded data set of the oxygen isotopic composition in seawater. Geophysical Research Letters 33, L12604. 10.1029/2006GL026011.

Li, Z., Powell, C., 2001. An outline of the palaeogeographic evolution of the Australasian region since the beginning of the Neoproterozoic. Earth Science Reviews 53, 237-277. 
Locarnini, R.A., Mishonov, A.V., Antonov, J.I., Boyer, T.P., Garcia, H.E., Baranova, O.K., Zweng, M.M., Johnson, D.R., 2010. World Ocean Atlas 2009 Volume 1: Temperature, in: Levitus, S. (Ed.), Ed. NOAA Atlas NESDIS 68. U.S. Government Printing Office, Washington, D.C.

Lohmann, K.C., 1988. Geochemical patterns of meteoric diagenetic systems and their application to studies of paleokarst, in: James, N.P., Choquette, P.W. (Eds.), Paleokarst. Springer-Verlag, Berlin, pp. 5080 .

Lowenstam, H.A., 1961. Mineralogy, ${ }^{18} \mathrm{O} /{ }^{16} \mathrm{O}$ ratios, and strontium and magnesium contents of Recent and fossil brachiopods and their bearing on the history of the oceans. Journal of Geology 69, 241-260.

Marland, G., 1975. The stability of $\mathrm{CaCO}_{3} \bullet \mathrm{H}_{2} \mathrm{O}$ (ikaite). Geochimica et Cosmochimica Acta 39, 83-91.

McClung, G., 1978. Morphology, palaeoecology and biostratigraphy of Ingelarella (Brachiopoda: Spiriferida) in the Bowen and Sydney basins of eastern Australia. Geological Survey of Queensland Publication 365, 17-60.

McClung, G., 1980a. Permian biostratigraphy of the northern Sydney Basin, in: Herbert, C., Helby, R. (Eds.), A guide to the Sydney Basin: Geological Survey of New South Wales Bulletin 26, pp. 361-375.

McClung, G., 1980b. Permian marine sedimentation, northern Sydney Basin. New South Wales Geological Survey Bulletin 26, 54-72.

Metcalfe, I., Crowley, J.L., Nicoll, R.S., Schmitz, M., 2014. High-precision U-Pb CA-TIMS calibration of Middle Permian to Lower Triassic sequences, mass extinction and extreme climate-change in eastern Australian Gondwana. Gondwana Research. http://dx.doi.org/10.1016/i.gr.2014.09.002.

Mii, H.-S., Grossman, E.L., 1994. Late Pennsylvanian seasonality reflected in the $\delta^{18} \mathrm{O}$ and elemental composition of a brachiopod shell. Geology 22, 661-664.

Mii, H.-S., Grossman, E.L., Yancey, T.E., 1997. Stable carbon and oxygen isotope shifts in Permian seas of West Spitsbergen - Global change or diagenetic artifact? Geology 25, 227-230.

Mii, H.-S., Grossman, E.L., Yancey, T.E., 1999. Carboniferous isotope stratigraphies of North America: Implications for Carboniferous paleoceanography and Mississippian glaciation. Geological Society of America Bulletin 111, 960-973.

Mii, H.-S., Grossman, E.L., Yancey, T.E., Chuvashov, B., Egorov, A., 2001. Isotopic records of brachiopod shells from the Russian Platform - evidence for the onset of mid-Carboniferous glaciation. Chemical Geology 175, 133-147.

Mii, H.-s., Shi, G.R., Cheng, C.-j., Chen, Y.-y., 2012. Permian Gondwanaland paleoenvironment inferred from carbon and oxygen isotope records of brachiopod fossils from Sydney Basin, southeast Australia. Chemical Geology 291, 87-103. 10.1016/j.chemgeo.2011.10.002.

Montañez, I.P., Poulsen, C.J., 2013. The Late Paleozoic ice age: An evolving paradigm. Annual Review of Earth and Planetary Sciences 41, 629-656. 
Mook, W., Vogel, J., 1968. Isotopic equilibrium between shells and their environment. Science 159, 874875.

Morgan, V.I., 1982. Antarctic ice sheet surface oxygen isotope values. Journal of Glaciology 28, 315-323.

Morrison, J.O., Brand, U., 1986. Geochemistry of Recent marine invertebrates. Geoscience Canada 13, 237-254.

Osborne, G.D., 1949. The stratigraphy of the Lower Marine Series of the Permian System in the Hunter River Valley, New South Wales. Proceedings of the Linnean Society of New South Wales 74, 203-223.

Pekar, S.F., DeConto, R.M., 2006. High-resolution ice-volume estimates for the early Miocene: Evidence for a dynamic ice sheet in Antarctica. Palaeogeography, Palaeoclimatology, Palaeoecology 231, 101-109. 10.1016/j.palaeo.2005.07.027.

Percival, I.G., Meakin, N.S., Sherwin, L., Vanderlaan, T.A., Flitcroft, P.A., 2012. Permian fossils and palaeoenvironments of the northern Sydney Basin, New South Wales. Geological Survey of New South Wales Quarterly Notes 138, 1-23.

Popp, B.N., Anderson, T.F., Sandberg, P.A., 1986. Brachiopods as indicators of original isotopic compositions in some Paleozoic limestones. Geological Society of America Bulletin 97, 1262-1269. 10.1130/0016-7606(1986)97<1262:baiooi>2.0.co;2.

Price, G.D., Nunn, E.V., 2010. Valanginian isotope variation in glendonites and belemnites from Arctic Svalbard: Transient glacial temperatures during the Cretaceous greenhouse. Geology 38, 251-254. 10.1130/g30593.1.

Rao, C.P., Green, D.C., 1982. Oxygen and carbon isotopes of early Permian cold-water carbonates, Tasmania, Australia. Journal of Sedimentary Petrology 52, 1111-1125.

Rees, P.M., Ziegler, A.M., Gibbs, M.T., Kutzbach, J.E., Behling, P.J., Rowley, D.B., 2002. Permian phytogeographic patterns and climate data/model comparisons. Journal of Geology 110, 1-31.

Reid, C.M., 2010. Environmental controls on the distribution of late Paleozoic bryozoan colony morphotypes: and example from the Permian of Tasmania, Australia. Palaios 25, 692-702.

Retallack, G.J., 2013. Permian and Triassic greenhouse crises. Gondwana Research 24, 90-103. http://dx.doi.org/10.1016/j.gr.2012.03.003.

Retallack, G.J., Sheldon, N.D., Carr, P.F., Fanning, M., Thompson, C.A., Williams, M.L., Jones, B.G., Hutton, A., 2011. Multiple Early Triassic greenhouse crises impeded recovery from Later Permian mass extinction. Palaeogeography, Palaeoclimatology, Palaeoecology 308, 233-251.

Roberts, J., Claoué-Long, J.C., Foster, C.B., 1996. SHRIMP zircon dating of the Permian System of eastern Australia. Australian Journal of Earth Sciences 43, 401-421.

Roberts, J., Offler, R., Fanning, M., 2006. Carboniferous to Lower Permian stratigraphy of the southern Tamworth Belt, southern New England Orogen, Australia: boundary sequences of the Werrie and Rouchel blocks. Australian Journal of Earth Sciences 53, 249-284. 
960

961

962

963

964

965

966

967

968

969

970

971

972

973

974

975

976

977

978

979

980

981

982

983

984

985

986

987

988

989

990

991

992

993

994

Runnegar, B., 1969a. The Permian faunal succession in eastern Australia. Geological Society of Australia Special Publication 2, 73-98.

Runnegar, B., 1969b. Permian fossils from the southern extremity of the Sydney Basin., in: Campbell, K.S.W. (Ed.), Stratigraphy and palaeontology, essays in honour of Dorothy Hill. Australian National University Press, Canberra, pp. 276-298.

Runnegar, B., 1970. Eurydesma and Glendella gen. nov. (Bivalvia) in the Permian of eastern Australia. Bureau of Mineral Resources, Geology and Geophysics, Australia, Bulletin 116, 83-106, pl. 113-118.

Runnegar, B., 1979. Ecology of Eurydesma and the Eurydesma fauna, Permian of eastern Australia. Alcheringa 3, 261-285.

Runnegar, B., 1980a. Biostratigraphy of the Shoalhaven Group. New South Wales Geological Survey Bulletin 26, 376-382.

Runnegar, B., 1980b. Marine Shoalhaven Group, southern Sydney Basin. New South Wales Geological Survey Bulletin 26, 74-81.

Runnegar, B., 1984. The Permian of Gondwanaland, Proceedings of the 27th International Geological Gongress, Moscow 4-14 August 1984, Volume 1, Stratigraphy. VNU Science Press, Utrecht, pp. 305-339.

Rygel, M.C., Fielding, C.R., Bann, K.L., Frank, T.D., Birgenheier, L.P., Tyes, S.C., 2008. The Lower Permian Wasp Head Formation, Sydney Basin: High-latitude, shallow marine sedimentation following the late Asselian to early Sakmarian glacial event in eastern Australia. Sedimentology 55, 1517-1540.

Sato-Okoshi, W., Okoshi, K., 2008. Characteristics of shell microstructure and growth analysis of the Antarctic bivalve Laternula elliptica from Lützow-Holm Bay, Antarctica. Polar Biology 31, 131-138. 10.1007/s00300-007-0340-9.

Schmidt, G.A., Bigg, G.R., Rohling, E.J., 1999. Global Seawater Oxygen-18 Database, Version 1.21, http://data.giss.nasa.gov/o18data/.

Schmidt, P., Clark, D.A., 2000. Paleomagnetism, apparent polar-wander path, and paleolatitude, in: Veevers, J.J. (Ed.), Billion-year Earth History of Australia and Neighbours in Gondwanaland. GEMCO Press, Sydney, pp. 12-17.

Schöne, B.R., 2008. The curse of physiology-challenges and opportunities in the interpretation of geochemical data from mollusk shells. Geo-Marine Letters 28, 269-285. 10.1007/s00367-008-0114-6.

Schöne, B.R., Fiebig, J., Pfeiffer, M., Gleß, R., Hickson, J., Johnson, A.L.A., Dreyer, W., Oschmann, W., 2005. Climate records from a bivalved Methuselah (Arctica islandica, Mollusca; Iceland). Palaeogeography, Palaeoclimatology, Palaeoecology 228, 130-148. 10.1016/j.palaeo.2005.03.049.

Schöne, B.R., Surge, D., 2012. Part N, Revised, Volume 1, Chapter 14: Bivalve sclerochronology and geochemistry. Treatise Online 46, 1-24.

Scotese, C.R., 1997. The Paleomap Project: paleogeographic atlas and plate tectonics software, Department of Geology, University of Texas. 
Scotese, C.R., 2001. Atlas of Earth History, Volume 1, Paleogeography. PALEOMAP Project, Arlington, TX.

996 Selleck, B.W., Carr, P.F., Jones, B.G., 2007. A review and synthesis of glendonites (pseudomorphs after 997 ikaite) with new data: assessing applicability as recorders of ancient coldwater conditions. Journal of 998 Sedimentary Research 77, 980-991.

Seuss, B., Titschack, J., Seifert, S., Neubauer, J., Nützel, A., 2012. Oxygen and stable carbon isotopes from a nautiloid from the middle Pennsylvanian (Late Carboniferous) impregnation Lagerstätte 'Buckhorn Asphalt Quarry' - Primary paleo-environmental signals versus diagenesis. Palaeogeography, 1002 Palaeoclimatology, Palaeoecology 319-320, 1-15. 10.1016/j.palaeo.2011.12.008. temperatures, and carbon cycling: A Southern Ocean perspective. Geochemistry, Geophysics, Geosystems 9, Q02006. 10.1029/2007GC001736.

1006 Sigman, D.M., Jaccard, S.L., Haug, G.H., 2004. Polar ocean stratification in a cold climate. Nature 428, 591007 63. http://www.nature.com/nature/journal/v428/n6978/suppinfo/nature02357 S1.html.

Slee, K.J., 1968. The geology of the Cranky Corner Basin, N.S.W.; Unpublished B.Sc. honours thesis. University of Newcastle.

Stampfli, G., Borel, G., 2002. A plate tectonic model for the Paleozoic and Mesozoic constrained by 1012 dynamic plate boundaries and restored synthetic oceanic isochrons. Earth and Planetary Science Letters 196, 17-33.

Stevenson, D.K., 2003. Stratigraphy, lithology and depositional setting of the Cranky Corner Basin. New 1014 South Wales Department of Mineral Resources Coal and Petroleum Bulletin 4, 15-50.

1015 Suess, E., Balzer, W., Hesse, K.-F., Müller, P.J., Ungerer, C.A., Wefer, G., 1982. Calcium carbonate 1016 hexahydrate from organic-rich sediments of the Antarctic Shelf: precursors of glendonites. Science 216, $1128-1131$.

Surge, D., Lohmann, K.C., Dettman, D.L., 2001. Controls on isotopic chemistry of the American oyster, Crassostrea virginica: implications for growth patterns. Palaeogeography, Palaeoclimatology, Palaeoecology 172, 283-296.

Sutherland, D.A., Pickart, R.S., Jones, E.P., Azetsu-Scott, K., Eert, A.J., Olafsson, J., 2009. Freshwater composition of the waters off southeast Greenland and their link to the Arctic Ocean. J. Geophys. Res. 114, 17. DOI:10.1029/2008JC004808 Wandrawandian Siltstone, New South Wales: Record of glaciation? Australian Journal of Earth Sciences $102654,1057-1071$.

1027 Towe, K.M., Hemleben, C., 1976. Diagenesis of magnesian calcite: evidence from miliolacean 1028 foraminifera. Geology 4, 337-339.

1029 Tucker, R.D., McKerrow, W.S., 1995. Early Paleozoic chronology: a review in light of new U-Pb ages from 1030 Newfoundland and Britain. Canadian Journal of Earth Sciences 32, 368-379. 
1031

1032

1033

1034

1035

1036

1037

1038

1039

1040

1041

1042

1043

1044

1045

1046

1047

1048

1049

1050

1051

1052

1053

1054

1055

1056

1057

1058

1059

1060

1061

1062

1063

1064

1065

Turekian, K.K., Armstrong, R.A., 1961. Chemical and mineralogical composition of fossil molluscan shells from the Fox Hills Formation, South Dakota. Geological Society of America Bulletin 72, 1817-1828.

Veizer, J., Ala, D., Azmy, K., Bruckschen, P., Buhl, D., Bruhn, F., Carden, G.A.F., Diener, A., Ebneth, S., Godderis, Y., Jasper, T., Korte, C., Pawellek, F., Podlaha, O.G., Strauss, H., 1999. ${ }^{87} \mathrm{Sr} /{ }^{86} \mathrm{Sr}, \delta^{13} \mathrm{C}$ and $\delta^{18} \mathrm{O}$ evolution of Phanerozoic seawater. Chemical Geology 161, 59-88.

Veizer, J., Bruckschen, P., Pawellek, F., Kiener, A., Podlaha, O.G., Carden, G.A.F., Jasper, T., Korte, C., Strauss, H., Azmy, K., Ala, D., 1997. Oxygen isotope evolution of Phanerozoic seawater.

Palaeogeography, Palaeoclimatology, Palaeoecology 132, 159-172.

Veizer, J., Fritz, P., Jones, B.G., 1986. Geochemistry of brachiopods: oxygen and carbon isotopic records of Phanerozoic oceans. Geochimica et Cosmochimica Acta 50, 1679-1696.

Walkom, A.B., 1912. Stratigraphical geology of the Permo-Carboniferous System in the MaitlandBranxton District, with notes on the Permo-Carboniferous palaeogeography in New South Wales. Proceedings of the Linnean Society of New South Wales 38, 146-159.

Warny, S., Askin, R.A., Hannah, M.J., Mohr, B.A.R., Raine, J.I., Harwood, D.M., Florindo, F., Team, t.S.S., 2009. Palynomorphs from a sediment core reveal a sudden remarkably warm Antarctica during the middle Miocene. Geology 37, 955-958. 10.1130/g30139a.1.

Waterhouse, J.B., 1963. New Zealand species of the Permian bivalve Atomodesma Beyrich. Palaeontology 6, 699-717.

Waterhouse, J.B., 1987. Late Palaeozoic Mollusca and correlations from the South-East Bowen Basin, East Australia. Palaeontographica Abt. B 198, 129-233.

Waterhouse, J.B., 2008. Golden spikes and black flags - macro-invertebrate faunal zones for the Permian of East Australia. Proceedings of the Royal Society of Victoria 120, 345-372.

Weidman, C.R., Jones, G.A., Lohmann, K.C., 1994. The long-lived mollusc Arctica islandica: A new paleoceanographic tool for the reconstruction of bottom temperatures for the continental shelves of the Northern Atlantic Ocean. Journal of Geophysical Research 99, 18,305-318,314.

Wilkinson, B.H., Ivany, L.C., 2002. Paleoclimatic inference from stable isotopic compositions of accretionary biogenic hardparts - a quantitative approach to the evaluation of incomplete data. Palaeogeography, Palaeoclimatology, Palaeoecology 185, 95-114.

Williams, D.F., Arthur, M.A., Jones, D.S., Healy-Williams, N., 1982. Seasonality and mean annual sea surface temperatures from isotopic and sclerochronological records. Nature 296, 432-434.

Winguth, A.M.E., Heinze, C., Kutzbach, J.E., Maier-Reimer, E., Mikolajewicz, U., Rowley, D., Rees, A., Ziegler, A.M., 2002. Simulated warm polar currents during the middle Permian. Paleoceanography 17, 91-9-18. 10.1029/2001pa000646.

Winton, M., 1997. The effect of cold climate upon North Atlantic Deep Water formation in a simple ocean-atmosphere model. Journal of Climate 10, 37-51. 
1066 Woolnough, W.G., 1910. Note on the occurrence of Eurydesma in the Upper Marine (Permo-

1067 Carboniferous) of New South Wales. Journal and Proceedings of the Royal Society of New South Wales

1068 44, 556-559.

1069 Zeng, J., Cao, C.-q., Davydov, V.I., Shen, S.-z., 2012. Carbon isotope chemostratigraphy and implications 1070 of palaeoclimatic changes during the Cisuralian (Early Permian) in the southern Urals, Russia. Gondwana 1071 Research 21, 601-610. 10.1016/j.gr.2011.06.002.

1072 